\title{
Zaznavanje, doživljanje in uporaba javnega odprtega prostora prebivalcev $v$ stanovanjskih soseskah mest
}

Javni odprti prostor $\mathrm{z}$ zelenimi površinami $\mathrm{v}$ mestih omogoča prebivalcem višjo kakovost bivanja. Zato je doživljanje, vedênje in uporaba odprtega prostora prebivalcev $\mathrm{v}$ mestih pomemben vir informacij za prostorsko načrtovanje. V praksi se je izkazalo, da se lahko pogledi načrtovalcev in uporabnikov močno razlikujejo. Šele obiskanost in uporaba odprtih prostorov pokaže, ali so bili ti ustrezno načrtovani. V prispevku sta na podlagi opravljene empirične raziskave v stanovanjskem območju Ljubljane predstavljena pomen in način pridobivanja podatkov o doživljanju in uporabi mestnega odprtega prostora pri prebivalcih. Namen članka je za potrebe načrtovalcev prepoznati dejavnike, ki pomembno vplivajo na zadovoljstvo prebivalcev v stanovanjskih soseskah. Uporabili smo metodo fokusnih skupin in metodo pridobivanja družbenoprostorskih obrazcev. Predvidevamo, da lahko večmetodni pristop da veljavnejše in zanesljivejše rezultate, ki so preverljivi in uporabnejši za pripravo načrtovalskih usmeritev. Predstavljeni izsledki raziskave kažejo, da prebivalci sosesko večinoma zaznavajo kot območje okrog svojega doma, v katerem se poznajo in družijo s sosedi. Dejavniki, ki sprožajo zadovoljstvo prebivalcev, so vzdrževane zelene površine $\mathrm{v}$ bližini doma, parki $\mathrm{z}$ drevesi in raznoliko programsko vsebino, drevoredi, povezava zelenih površin v sistem, možnost uporabe površin za rekreacijo in šport ter urbane opreme za počitek in igro. Prostorski elementi, ki otežujejo uporabo odprtega prostora, so predvsem obremenjene prometne ulice, nezavarovani prehodi za pešce, večja območja garaž in parkirnih površin.

Ključne besede: javni odprti prostor mest, zelene površine, stanovanjske soseske, doživljanje bivalnega okolja, fokusna skupina, družbenoprostorski obrazec, urbanistično načrtovanje, Ljubljana 


\section{Uvod}

Javni odprti prostori mesta so vsa tista območja, ki so odprta za prosto izbrane in spontane dejavnosti ljudi (Lynch, 1960). Namenjeni so prebivalcem in obiskovalcem mesta ter so javni glede rabe, medtem ko je zasebni odprti prostor (vrtovi, dvorišča) namenjen samo lastniku in njegovi uporabi. Odprti prostor mest sestavljajo zelene in druge površine, ki naj bi zadovoljevale različne potrebe prebivalcev in obiskovalcev. Zelene površine so zelenice $s$ trato, okrasni nasadi, parki, drevoredi, otroška igrišča, zelene površine pred in med večstanovanjskimi stavbami, vrtovi, pokopališča, naravna območja z gozdom ipd. Druge odprte površine mesta pa so tista območja, ki niso ozelenjena, kot so tlakovane površine igrišč, športnih površin, sprehajalnih in kolesarskih poti, dvorišč, trgov, ploščadi ipd. Odprti javni prostori naj bi bili načrtovani tako, da bi uporabnikom nudili možnost izbire različnih dejavnosti. $V$ tem prispevku obravnavamo predvsem javni odprti prostor mest. Zelene površine smo v prispevku še posebej poudarili, saj tvorijo najpomembnejše funkcionalne odprte prostore, zaradi katerih je življenje v mestu prijetnejše in kakovostnejše.

Različni pomeni in funkcije odprtega prostora mest omogočajo nastanek povezav med prostorom in osebo kot uporabnikom. Ljudje se namreč običajno povezujejo s svojim fizičnim in socialnim okoljem. Privlačnost javnega odprtega prostora mest se pri uporabnikih razvije takrat, kadar okolje postane pomemben del njihovega vsakdanjega življenja ter zadovoljuje njihove potrebe in interese. Stephen Carr idr. (1992) menijo, da se različni vidiki javnega odprtega prostora kažejo v možnostih, ki jih nudijo uporabnikom, kot so odzivnost, demokratičnost in pomen. Odzivni odprti prostori mest so tisti, ki zadovoljujejo različne potrebe uporabnikov, na primer udobje, sprostitev, dejavna in nedejavna zaposlitev, raziskovanje in druženje. Celoviti odprti prostori omogočajo raznovrstne rabe in so dostopni različnim skupinam ljudi (demokratični prostori). Prebivalcem in obiskovalcem omogočajo začasno prisvajanje in nadzor, dajejo pa jim tudi možnosti za druženje. Prostor dobi pomen, ko se med okoljem in uporabnikom vzpostavi močna povezava. $V$ stanovanjskih soseskah se običajno razvije občutek pripadnosti in varnosti posameznika, ki se prek storitev in druženja povezuje $\mathrm{z}$ družbo. Zato imajo odprti prostori $\mathrm{v}$ stanovanjskih soseskah še posebej pomembno vlogo, saj naj bi omogočali in spodbujali druženje in povezovanje prebivalcev.

Človekovo okolje je dvojne narave: fizično okolje vsakdanjega bivanja in družbeno okolje medsebojnih odnosov. Na doživljanje, uporabo in vedênje prebivalcev v prostoru vplivajo tudi demografski, socialni, psihološki in kulturni dejavniki. Roger Barker (1968) meni, da vedênja uporabnikov prostora ne moremo opredeliti zunaj okolja, v katerem se to pojavlja, ker oba ponazarjata del iste celote. Zato poudarja, da predmet proučevanja ni vedênje uporabnika samo po sebi, ampak celota njegovega vedênja - okolje. Brez upoštevanja zakonitosti človeškega doživljanja (psihološki vidik) in delovanja okolja (okoljsko-prostorski vidik) bivalnega okolja ne bomo mogli izboljšati. Številni raziskovalci (na primer Proshansky, 1972; Lewin, 1974; Mehrabian in Russell, 1974; Gifford, 1987; Cassidy, 1997; Bechtel, 1997, Bechtel idr., 2002, in Zeisel, 2006) so opozorili na tesno povezanost človeka, njegovega vedênja in okolja kot življenjskega prostora.

Upoštevanje doživljanja, dojemanja in uporabe javnega odprtega prostora prebivalcev v mestih je pomembno za uspešno izvajanje uporabnikom prijaznega prostorskega načrtovanja. Ker pa subjektivna občutenja in vrednote uporabnikov niso neposredno razvidni, jih načrtovalci pogosto ne upoštevajo, posledično pa prostor morda ne ustreza njihovim potrebam. Prav zato je raziskovanje omenjenih vidikov nujno za kakovostno načrtovanje prostora. Na razhajanja med pogledi načrtovalcev in uporabnikov so opozorili že raziskovalci v sedemdesetih letih prejšnjega stoletja (na primer Proshansky, 1972; Porteous, 1977, ter Wandersman, 1976 in 1979). Čeprav je ta odnos pomemben, načrtovalci prostora večinoma še vedno zanemarjajo vlogo in mnenje uporabnikov. Mnogi avtorji (na primer Cooper, 1998; Bratina, 1997, Goličnik, 2005; Jole, 2008, in Jacobs, 2009) so na podlagi raziskav opozorili, da se lahko pogledi ter stališča uporabnikov in načrtovalcev prostora močno razlikujejo. Po izvedbi projekta oblikovalce oziroma načrtovalce le redko zanimajo odzivi uporabnikov. Osnovni kazalnik, ali ljudem odprti prostori mesta ustrezajo, sta njihova obiskanost in načini uporabe. Jane Jacobs (2008) navaja, da so parki v soseskah, ki jih ljudje pogosto in množično uporabljajo, uspešni in dobro načrtovani. Parki, ki niso obiskani, ker niso zanimivi ali ustrezni, so s tem podvrženi propadanju.

$\mathrm{V}$ prispevku sta predstavljena pomen in način pridobivanja podatkov o doživljanju in uporabi mestnega odprtega prostora pri prebivalcih, nakazane pa so tudi možnosti vključevanja pridobljenih ugotovitev $\mathrm{v}$ urbanistično načrtovanje. $\mathrm{V}$ enem od ljubljanskih stanovanjskih območij smo raziskovali mnenje prebivalcev o javnem odprtem prostoru, njihovo doživljanje tega in uporabo. Cilj je bilo prepoznavanje dejavnikov, ki vplivajo na zadovoljstvo prebivalcev, in njihova prostorska opredelitev. Uporabili smo kombinacijo metode fokusnih skupin in metode pridobivanja družbenoprostorskih obrazcev. Menimo, da večmetodni pristop lahko da veljavnejše in zanesljivejše rezultate, ki so uporabnejši pri pripravi načrtovalskih usmeritev. Če podatki, pridobljeni z različnimi metodami, niso skladni, lahko rezultat opozori ali na vsebinska protislovja v naravi proučevanega pojava ali na neustrezno izbiro metod. $V$ prvem delu prispevku je prikazana vloga zelenih površin v mestu in njihovo načrtovanje, stanje obstoječih zelenih površin $\mathrm{v}$ stanovanjskih 
soseskah v Ljubljani in pomen vključevanja javnosti za boljše urbanistično načrtovanje. $\mathrm{V}$ drugem delu so predstavljeni uporabljeni metodi in izsledki empirične raziskave ${ }^{[1]}$. Obravnava se konča s prikazom uporabe pridobljenih podatkov za načrtovanje odprtih prostorov mesta.

\section{Pomen zelenih površin v mestu}

Danes več kot polovica ljudi živi v mestih, pred sto leti pa je ta naseljevalo le približno $10 \%$ vsega prebivalstva. Število prebivalcev v mestih in stopnja urbaniziranosti stalno narašča. Avstralija, Nova Zelandija, Severna Amerika in Evropa so najbolj urbanizirani deli sveta, $\mathrm{v}$ katerih deleži urbanega prebivalstva dosegajo od 75 do $80 \%$ (SLONEP, 2011). V Sloveniji živi v urbanih območjih skoraj $50 \%$ prebivalcev $^{[2]}$. Na kakovost bivanja ljudi v mestih vplivajo predvsem gostota prebivalstva, način bivanja in raba mestnih zemljišč. Zelo pomemben je obstoj zelenih in drugih odprtih površin, saj ta opravljajo več različnih funkcij. So pomembna območja vsakdanje sprostitve prebivalcev in doživetja narave v mestu ter ohranjanja zdravja. Namenjena so igri in rekreaciji, imajo pa tudi pomembno vlogo pri oblikovanju podobe mesta.

Zaradi vse večje gostote poseljenosti v mestih izjemno narǎ̌ča potreba prebivalcev po zelenih in drugih odprtih površinah. Prebivalci iščejo možnosti za neposreden stik z naravo in zelenim okoljem v svojem bivalnem okolju. Zato je pomembno, da je v odprtih prostorih mestih veliko zelenih površin z drevesi in raznolikim rastjem. $V$ raziskavi 386 evropskih mest o pokritosti z zelenimi površinami (Fuller in Gaston, 2009) je podatek, da znaša povprečje pokritosti $18,6 \%$ območja mesta. Najmanjši delež zelenih površin (1,9\% mesta) je v Reggio di Calabria v Italiji, največji delež ( $46 \%$ mesta) pa v Ferrolu v Španiji. V analizi obsega zelenih površin na prebivalca mesta so ugotovili, da je najmanjša površina $3-4 \mathrm{~m}^{2}$ na prebivalca v španskih (Cadiz, Fuenlabrada in Almeria) in italijanskih mestih (Reggio di Calabria). Največ zelenih površin (več kot $300 \mathrm{~m}^{2}$ ) na prebivalca je v Belgiji (Liege), na Finskem (Oulu) in v Franciiji (Valenciennes). Primerjava med evropskimi mesti, zajetimi v raziskavo, pokaže, da je delež zelenih površin na prebivalca najnižji v mestih na jugu in vzhodu Evrope, največji pa na severu in severozahodu Evrope. Med prestolnicami je Dunaj mesto, ki je zelo dobro pokrito z zelenimi površinami, saj okrog 50 \% mesta z okolico obsegajo zelene površine. Dunaj so večkrat zapored razglasili za svetovno metropolo z najvišjo kakovostjo življenja (mednarodno podjetje Mercer), imenujejo pa ga tudi zeleno mesto (Wien International, 2014). Tudi Berlin je sodobna evropska prestolnica z veliko zelenih površin, ki izstopa predvsem z zelenimi površinami velikih razsežnosti. Odprt prostor nekdanjega letališča Tempelhof (Trajekt - Zavod za prostorsko kulturo, 2012) je na podlagi dobrega na- črtovanja postal odličen primer revitalizacije velikega degradiranega urbanega območja mesta v urbani park 21. stoletja.

Ljubljana se z zelenimi površinami, vzpetinama, poraščenima $\mathrm{z}$ gozdom, ki se zajedata $\mathrm{v}$ samo središče mesta, in $\mathrm{s}$ svojim naravnim zaledjem uvršča med zelena evropska mesta, saj $44 \%$ površin celotne Mestne občine Ljubljana (Odlok o občinskem prostorskem načrtu Mestne občine Ljubljana - izvedbeni del, Ur. l. RS, št. 78/2010) pokrivajo zelene površine (javne in zasebne). Po podatkih Mestne občine Ljubljana (2010) je javnih zelenih površin v glavnem mestu Slovenije $19 \%$ (glede na vse zelene površine celotne občine Ljubljana) oziroma 1778 ha, kar znaša $66 \mathrm{~m}^{2}$ na prebivalca. Petra Vertelj Nared in Maja Simoneti (2011) poudarjata, da so navedeni podatki sicer pomembni, vendar pa prebivalci mesta dejansko nimajo na voljo tako velike strnjene površine, temveč številne majhne površine, ki so v zelo različnem stanju, ponekod celo neuporabne za razvoj in rast dreves. Navajata, da znaša delež zelenih površin v strnjenem delu mesta, le 6,5 \% glede na vse zelene površine Mestne občine Ljubljana (Vertelj Nared in Simoneti, 2011). Davorin Gazvoda (2001) opozarja, da z urbanizacijo postopoma vse bolj izginjajo manjše zelene in odprte površine v slovenskih mestih. Obenem v Ljubljani opažamo, da so zelene in druge odprte površine slabo vzdrževane prav na območjih stanovanjskih sosesk, na zelenicah med večstanovanjskimi objekti, ki so zelo pomembne za vsakdanjo uporabo in zagotavljanje boljše kakovosti bivanja prebivalcev. Večina prebivalcev Ljubljane, skoraj

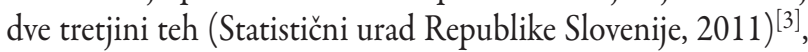
živi v stanovanjih $\mathrm{v}$ večstanovanjskih stavbah ali blokih brez svojih zelenih in drugih odprtih površin. Tretjina prebivalcev slovenske prestolnice živi v enostanovanjskih hišah, za katere sklepamo, da imajo vsaj nekaj svojega vrta oziroma zelenih površin ob hiši, večina pa biva v večstanovanjskih objektih brez takih površin. Zato domnevamo, da obstaja $\mathrm{v}$ stanovanjskih soseskah Ljubljane velika potreba po javnih zelenih površinah in uporabi odprtega prostora v bivalnem okolju.

Werner Lendholt (1970) je na prvi mednarodni konferenci o pomenu zelenih površin, ki je bila organizirana v Ljubljani, navedel primer novozasnovane stanovanjske soseske v Bremnu v Nemčiji, v kateri so bili kakovostno urejeni odprti prostori soseske za stanovalce skoraj pomembnejši kot stanovanjske stavbe. Kupci se velikokrat odločajo za stanovanja, ki so umeščena v kakovostnejše bivalno okolje oziroma pri katerih je » mikrolokacija « odprtega prostora okrog stanovanja in širše v soseski urejena z zelenimi površinami (Noiseux idr., 2010). Po Hansu Skifterju Andersenu (2011) je eden od šestih pomembnih dejavnikov kakovosti bivanja (preferenc do izbire okolice in lokacije doma) »bližina narave in mirne okolice «. Tudi Rachel Kaplan idr. (1998) navajajo, da naravno okolje v urbanih območjih spodbuja dobro počutje prebivalcev in da lahko izboljša sposobnost ljudi za učinkovito delovanje. Da 


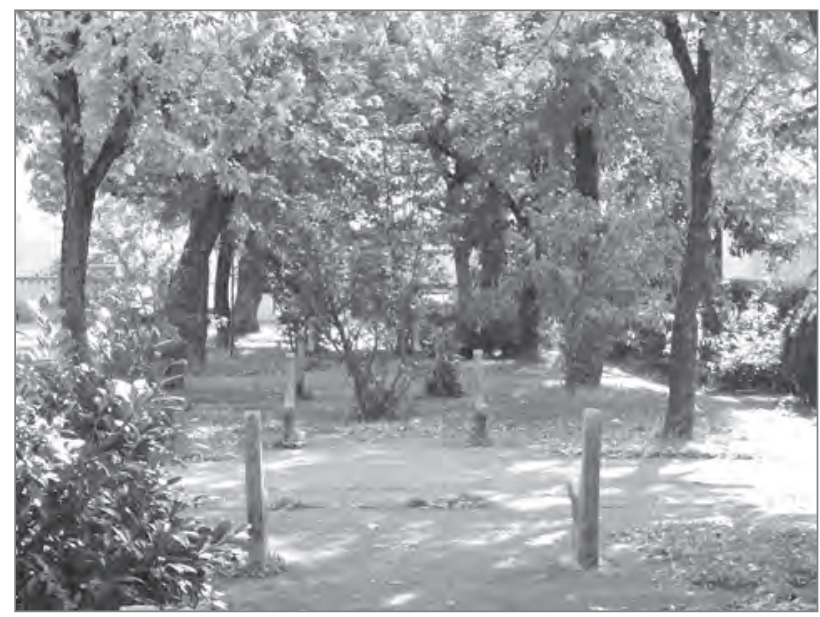

Slika 1: Zanemarjena urbana oprema na zelenih površinah med stanovanjskimi bloki na območju raziskave v Ljubljani (foto: Nataša Bratina Jurkovič)

se pomen zelenih površin in zasajenega rastlinja v mestu v zadnjem času izjemno povečuje, potrjujejo različne raziskave (na primer Kearney 2006; Noiseux idr., 2010, Ward Thompson, 2010; Sullivan, 2011; Kyttä, 2011, in Jankovič Grobelšek, 2012), v katerih avtorji predstavljajo pomen kakovostnega bivalnega okolja z zelenimi površinami za zdravje in dobro počutje prebivalcev. Uvaja se tudi izraz »zdravo okolje « (ang. salutogenic environment, Kyttä, 2011), ki se uporablja za bivalno okolje, ki podpira zdrav način življenja. Navedeno kaže, da odprti zeleni prostori pomembno pozitivno vplivajo na vedênje in zdravje ljudi.

V pravnih aktih s področja prostorskega načrtovanja na državni in lokalni ravni je pri opredeljevanju pomena zelenih površin poudarjeno izboljšanje kakovosti bivanja, zagotavljanje pogojev za zdravo življenje, druženje in rekreacijo in vzpostavljanje zelenega sistema mesta. Opredeljeni so standardi ${ }^{[4]} \mathrm{za}$ določitev velikosti območij zelenih in drugih odprtih površin, določena pa je tudi primerna dostopnost ${ }^{[5]}$ prebivalcev do teh površin. Kljub jasnim zahtevam v prostorskonačrtovalski zakonodaji v praksi načrtovanje ter izvedba zelenih in drugih odprtih površin večinoma potekata $\mathrm{v}$ smeri zmanjševanja obstoječih površin, predvsem zaradi interesov za gradnjo in $s$ tem zgoščevanja stavbnega tkiva. Prisotnost in velikost zelenih površin sta le dve od meril za zagotavljanje kakovosti bivanja $\mathrm{v}$ odprtem prostoru. Pomembni so tudi njihova urejenost in dobra programska zasnova ter dostopnost za prebivalce in druge uporabnike. Javnost sprejema zelene in druge odprte površine v odvisnosti od njihovih lastnosti, kot so razpoložljivost, kakovost in dostopnost. Trendi, ki so opazni v številnih evropskih mestih, kažejo, da se kakovost obstoječih mestnih zelenih površin v splošnem slabša (Smaniotto Costa idr., 2008). Prav zaradi vse večje pozidave odprtega mestnega prostora v Ljubljani (Cigoj in Gazvoda, 2008) in ponekod opušcanja oziroma slabega vzdrževanja obstoječih zelenih površin v soseskah (slika 1) se prebivalci vse bolj zavedajo, kako pomembne so zelene površine. V praksi se prebivalci zelo ostro javno odzovejo, kadar gre za odvzem, zmanjšanje ali celo ukinitev obstoječih zelenih površin na račun gradnje novih objektov v strukturi mesta.

\section{Pomen vključevanja prebivalcev v urbanistično načrtovanje}

Pred uvajanjem razvojnih sprememb in večjih posegov je treba dobro spoznati mesto, njegov javni odprti prostor in življenje v soseskah. Lia Ghilardi (glej Megla, 2012) navaja primer New Yorka, v katerem so predeli, ki so nastali organsko in spontano. Soseska in mesto sta podprla tisto, kar je tam naključno nastalo in se uspešno razvijalo. Zelene površine, ki so nastale vzdolž zapuščene železniške proge, so nadgradili s projektom. Razumeli so, da lokalna skupnost potrebuje park, v katerem se lahko ljudje družijo, počivajo in uživajo na zelenih površinah, med rastlinjem in drevesi. Namesto da bi degradirano območje pustili, kakršno je bilo, so ga ozelenili in ustvarili kakovosten javni prostor. Podobno se je zgodilo v Parizu leta 2007, ko so del opuščnih železniških prog ob strnjenem naselju stanovanjskih blokov spremenili v dinamičen park Jardins d'Eole z otroškimi in s športnimi igrišči, sprehajalnimi potmi, z območji za druženje in počitek (slika 2), kar je izboljšalo vsakdanje življenje v soseski in omogočilo kakovostno preživljanje prostega časa (glej Jole, 2008).

Pred načrtovanjem in uvajanjem sprememb moramo spoznati način življenja ter uporabo in doživljanje odprtih prostorov mesta. Aktivna vključitev prebivalcev stanovanjskih območij $\mathrm{v}$ prostorsko načrtovanje je zelo priporočljiva že $\mathrm{v}$ začetni fazi tega načrtovanja. Tako se lahko izognemo konfliktnim okoliščinam, do katerih pogosto pride med prebivalci in načrtovalci večjih posegov v odprti prostor stanovanjskih sosesk. Zastavlja se vprašanje, kako odkriti, kaj prebivalci potrebujejo, si želijo, kako uporabljajo odprti prostor in zelene površine, kakšen pomen imajo te zanje, za zadovoljevanje njihovih potreb in zagotavljanje bolǰ̌e kakovosti bivanja.

Številni avtorji (na primer Gulič idr., 1985; Rus idr., 1994; Simoneti, 1996; Bratina, 1997; Abu-Ghazzeh, 1999; Goličnik, 2005 in 2006; Jole, 2008; Kyttä, 2011; Bizjak, 2012, ter Ho idr., 2012) ugotavljajo, da je načrtovanje odprtega urbanega prostora veliko kakovostnejše, če se prebivalci vključijo že v zgodnjo fazo načrtovanja. Richard Sendi (2006) meni, da dobra prenova sosesk ni mogoča brez aktivnega sodelovanja prebivalcev. Po drugi strani Maja Simoneti (1996) poudarja, da bi bilo smiselno uveljaviti več načrtnega vključevanja prebivalcev v urejanje in vzdrževanje javnih zelenih površin. Na pomen sodelovanja med načrtovalci in uporabniki odprtega prostora opozarja tudi Barbara Goličnik (2005). Michele Jole (2008) 

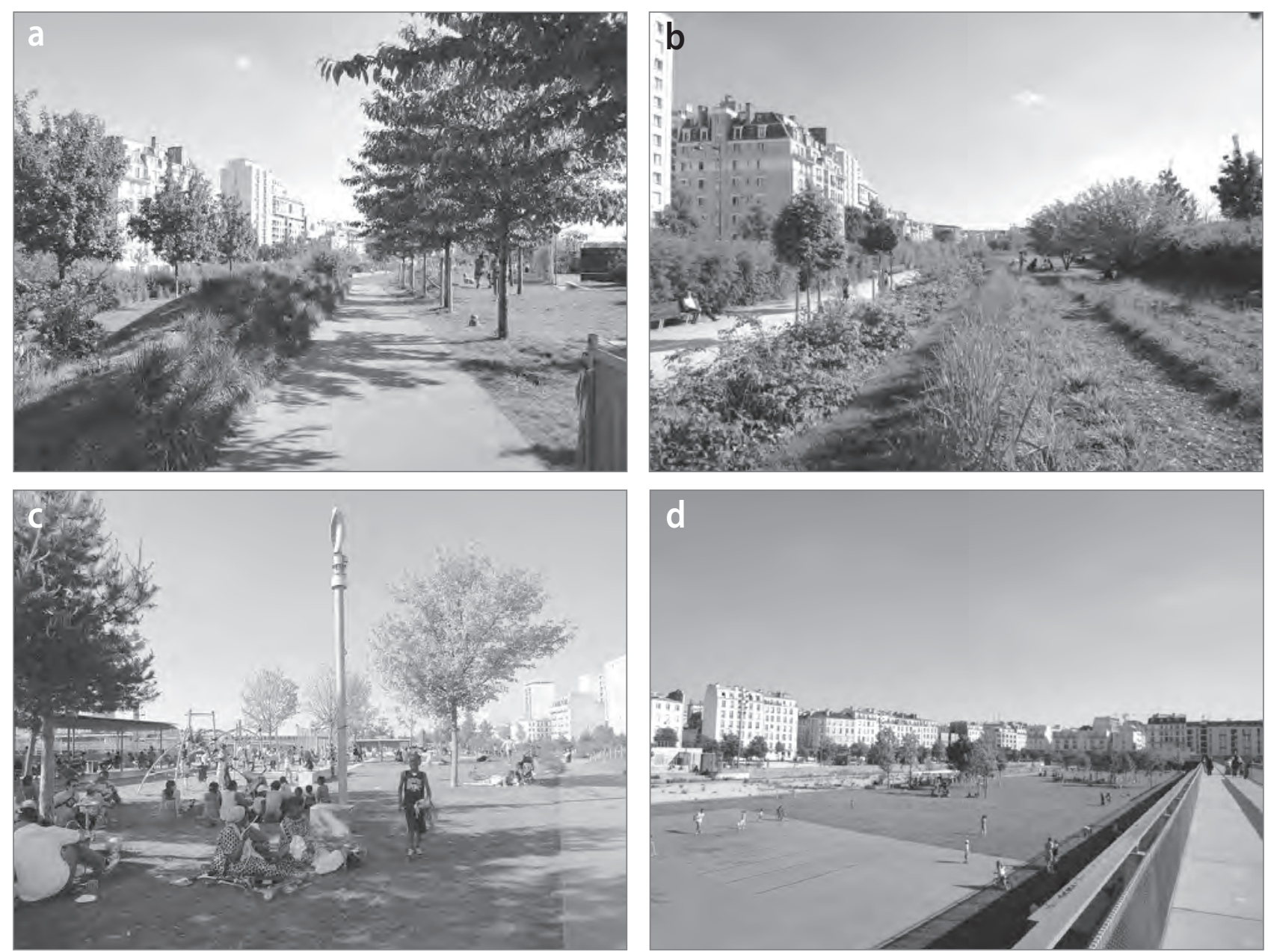

Slika 2: Park Jardins d'Eole v pariški soseski La Villette je nastal na območju dela opuščenih železniških prog. Prikaz območja: (a) osrednji del, (b) sprehajalna pot ob stanovanjskih blokih, (c) otroško igrišče, (d) ploščad in travnik ter na desni rob, ki meji na železniško območje (foto: Nataša Bratina Jurkovič).

poudarja pomen upoštevanja družbene dimenzije v načrtovanju in izgradnji javnih parkov na primeru Pariza, Nataša Bratina (1997) pa na osnovi raziskave v Novi Gorici navaja, da so za proučevanje doživljanja mestnega odprtega prostora pri uporabnikih najpomembnejši psihološki in strukturni vidik ter vidik socialne uporabnosti. Psihološki vidik se navezuje na neposredno doživljanje in dojemanje prostora, strukturni vidik pa kaže, da so javni mestni prostori pomembna prostorska kategorija v zgradbi mesta. Nataša Bratina (1997) dalje navaja, da je za pridobivanje tovrstnih podatkov najprimernejša povezava različnih metod (večmetodni pristop), pri kateri uporabniki neposredno sodelujejo in izražajo mnenja. Po Johnu Zieselu (2006) ne moreš vedeti, kako ljudje dojemajo prostor in ga doživljajo, če jih o tem ne vprašaš. Na pomembnost raziskovanja odnosov med urbanimi strukturami in izkušnjami prebivalcev opozarja Marketta Kyttä (2011). Poudarja potrebo po izvajanju več tovrstnih raziskav, ne samo na splošni ravni, ampak na konkretnih območjih bivanja. Navaja, da se morajo konkretne prostorske raziskave nanašati na uporabnike, ki prostor doživljajo in uporabljajo, ter na objekt oziroma območje zaznavanja in doživljanja. Ugotavlja tudi, da ljudje svoje bivalno okolje bolj pozitivno doživljajo v soseskah $\mathrm{z}$ manjšo gostoto kot $\mathrm{v}$ večjih soseskah z veliko gostoto bivanja. Poudarja pa tudi, da je v urbanem načrtovanju uporaba raziskav in teorij okolijske psihologije še vedno zelo redka. V prihodnje bi morala biti po njenem mnenju stroka dojemljivejša za te raziskave, kar naj bi bila naloga oblikovalcev in načrtovalcev prostora.

Čeprav ima bivalno okolje velik vpliv na zadovoljstvo in dobro počutje prebivalcev, mnogi avtorji ugotavljajo (Frick, 1986; Cooper, 1998, in Massam, 2002), da urbanisti in oblikovalci večinoma niso naredili presežka pri oblikovanju okolja prav v stanovanjskih soseskah, $\mathrm{v}$ katerih naj bi ljudje živeli udobno in uživali kar največjo kakovost $\mathrm{v}$ odprtem prostoru za vsakdanjo rabo. Sodelovanje prebivalcev in možnost vpliva na odločitve o načrtovanju prostora, da bi se izboljšala kakovost življenja v stanovanjskih območjih, sta nujna. Če načrtovalci in oblikovalci ne poznajo potreb in želja ljudi, ki živijo v določeni stanovanjski soseski, potem ne morejo ustrezno načrtovati in poskrbeti za izboljšave v teh skupnostih. Terry L. Cooper (1998) trdi, da 
Preglednica 1: Vprašanja za izvedbo fokusnih skupin

\begin{tabular}{ll}
\hline vrsta vprašanja & vprašanje \\
\hline otvoritveno & Prosim, predstavite se in povejte, kako dolgo že živite v tej soseski. \\
\hline uvodno & 1. Ali v prostem času uporabljate zelene in druge odprte površine v svoji soseski? Kako pogosto jih uporabljate? \\
\hline 2. Kako ste zadovoljni z urejenostjo zelenih površin v soseski? \\
3rehodno
\end{tabular}

je naloga odgovornih iz javne uprave, da spodbujajo prebivalce, da sodelujejo v procesu odločanja, še posebej kadar se to nanaša na načrtovanje novih vsebin ali prenovo njihove stanovanjske soseske. Cliff Moughtin (2003) dodaja, da je zelo pomembno za načrtovalce in oblikovalce, da poslušajo prebivalce oziroma uporabnike ter upoštevajo njihova mnenja, poudarjene probleme in tudi njihove predloge. Tovrstno sodelovanje bi po njegovem mnenju lahko učinkovito pomagalo zmanjšati razlike, ki velikokrat obstajajo med načrtovalci in uporabniki. Zato je treba podatke o doživljanju in dejanski rabi javnih mestnih prostorov pridobiti z opazovanjem vedênja uporabnikov odprtih mestnih prostorov in vključevanjem teh $\mathrm{v}$ neposredno izražanje, kot tudi z upoštevanjem njihovega mnenja o rabi odprtega prostora na območju njihovega bivanja.

\section{Metoda}

Za raziskovanje zaznavanja, doživljanja in uporabe odprtega prostora prebivalcev stanovanjskih sosesk smo uporabili povezavo dveh metod: metodo fokusnih skupin in metodo pridobivanja družbenoprostorskih obrazcev. $S$ prvo metodo pridobimo mnenje udeležencev o različnih vprašanjih dojemanja in uporabe okolja, $\mathrm{z}$ drugo pa podatke natančneje umestimo $\mathrm{v}$ prostor. Poskušali smo dobiti odgovore na ta sklopa vprašanj:

(a) Doživljanje in zaznavanje prostora pri prebivalcih:

- zaznava možnosti za zadovoljevanje potreb v odprtem prostoru,

- pomembnost posameznih vidikov odprtega prostora in njihove sestave za doživljanje prostora,
- vpliv odprtega prostora na počutje in zadovoljstvo,

- zaznava in določanje prostora soseske,

- povezanost prebivalcev s sosednjimi območji.

(b) Uporaba odprtega prostora v stanovanjskih soseskah pri prebivalcih:

- na katerih območjih se zadržujejo in kako jih uporabljajo,

- možnosti oziroma omejitve za zadovoljevanje potreb,

- uporaba elementov urbane opreme,

- priljubljenost območij v soseski,

- razmerje med uporabo območij znotraj in zunaj soseske.

Metoda fokusnih skupin je oblika skupinskega pogovora, pri kateri so udeleženci neposredno vključeni v sodelovanje in izražanje mnenja. Gre za srečanje manjše skupine ljudi (od 6 do največ 12 udeležencev), ki se usmerjeno pogovarja o vnaprej določeni temi (Flick, 2009). Tako pridobimo podatke o pogledih udeležencev v kontekstu pogledov drugih udeležencev. Pogovor poteka po opredeljenem načrtu raziskovalca oziroma po vnaprej določenih vprašanjih. Uporabnost metode fokusnih skupin (glej Stewart, 2007; Barbour, 2007; Flick, 2009; Zeisel, 2006, in Šarić, 2007) je predvsem v tem, da omogoča vpogled $\mathrm{v}$ raznolikost mnenj, ki jih imajo udeleženci o določeni temi.

Grafični in drugi vidni pristopi (spoznavni zemljevidi), s katerimi pokušamo ugotoviti, kako si ljudje predstavljajo okolje in prostorske odnose, nudijo uporabne podatke za prostorsko načrtovanje (Polič idr., 2002). Posredujejo posameznikovo 
podobo prostora, ki je rezultat spoznavne preslikave okolja z lokacijsko in vsebinsko informacijo. Metoda pridobivanja družbenoprostorskih obrazcev (Lee, 1976) je ena od takih metod. Udeleženci na kartografskem zemljevidu kraja obkrožijo območje, ki ga najpogosteje uporabljajo, imajo za svoje, jim je všeč in podobno. Metoda je bila največkrat uporabljena za ugotavljanje območja sosesk. Polič idr. (1991) so jo v raziskavi dojemanja lokalne skupnosti uporabili tudi za ugotavljanje območij, ki jih prebivalci doživljajo kot neprijetna. Prednost te metode je, da dokaj natančno prostorsko umesti odgovore udeležencev.

V raziskavi smo izvedli tri fokusne skupine. Delo je potekalo po vnaprej oblikovanem opomniku z 12 vprašanji (preglednica 1), ki so se nanašala predvsem na zelene in druge odprte površine, njihovo stanje, kakovost in uporabo. Za pridobivanje družbenoprostorskih obrazcev smo uporabili barvni kartografski zemljevid mesta, ki je prikazoval območje raziskave. Udeleženci so morali na zemljevidu označiti določene kraje in območja (dom, soseska, prijetna in neprijetna območja).

\subsection{Območje}

V raziskavo smo vključili stanovanjske soseske na območju šolskega okoliša Osnovne šole dr. Vita Kraigherja v četrtni skupnosti Bežigrad v Ljubljani ${ }^{[6]}$. Tam so pretežno stanovanja s športnimi površinami in z objekti, zelenimi površinami, najnujnejšimi servisnimi storitvami (trgovine, pekarna, frizer, kozmetični salon, urar, optik, lokali, restavracije, osnovna šola, trije vrtci, cerkev, knjižnica, policijska postaja idr.), manjšimi podjetji in obrtnimi delavnicami. Osrednji del območja opredeljujejo osnovna šola $s$ kompleksom športnih igrišč, mestni park in otroško igrišče (slika 5), tlakovana ploščad, ki deluje kot trg (slika 6), ter ulica z drevoredom (slika 7), ki je za pešce in kolesarje osrednja povezava do centra mesta. Okrog osrednjega območja se mešajo stanovanjske soseske blokov in enodružinskih hiš z vrtovi (atrijske, vrstne in samostojne hiše). Ob zahodnem robu, ki ga omejuje železniška proga, je manjše železniško postajališče. Vzdolž proge so stavbe z obrtnimi in $s$ podjetniškimi dejavnostmi, ki se mešajo s pretežno enodružinsko stanovanjsko gradnjo. V tem območju je nekaj zanemarjenih in opuščenih zgradb, ki razpadajo ter dajejo območju značaj neurejenosti in degradiranosti (slika 13).

V primerjavi z drugimi deli mesta je na območju raziskave veliko zelenih površin. Večinoma so to manjše slabše urejene zelenice med bloki (slika 8), nekaj drevoredov vzdolž ulic, večji mestni park z veliko drevesi in otroškim igriščem ter nekaj posameznih zelenic s slabo vzdrževanimi igrali za otroke in klopmi, nekaj kolesarskih poti in redkih poti, namenjenih samo pešcem, ter zasebne zelene površine, kot so vrtovi ob stanovanjskih hišah. Neposredno ob robovih območja so še novejši sodobni mestni park z otroškim igriščem (slika 9), sprehajalna in kolesarska pot, ki obdaja Ljubljano ter povezuje med seboj zelene površine in predele mesta. Odprte površine, urejene za rekreacijo in šport, so kompleks športnih igrišč za šolo, na zahodnem robu čez železniško progo pa je tudi športni park za atletiko, nogomet, tenis in tek.

\subsection{Udeleženci}

K sodelovanju $\mathrm{v}$ fokusnih skupinah smo povabili odrasle prebivalce (starejše od 18 let), ki živijo na območju šolskega okoliša. Povabili smo jih osebno z dopisom po elektronski pošti, v katerem smo pojasnili namen, vsebino sodelovanja v skupini in potek dela. Večina povabljenih $(90 \%)$ se je na povabilo odzvala in sodelovala $\mathrm{v}$ fokusni skupini. To so bili starši otrok, ki obiskujejo Osnovno šolo dr. Vita Kraigherja, ter drugi mladi in starejši prebivalci. Skupaj je v treh fokusnih skupinah sodelovalo 27 oseb, od tega sedem moških in 20 žensk. Med sodelujočimi je bila tudi oseba s posebnimi potrebami na invalidskem vozičku. Udeleženci posamezne skupine so se večinoma poznali med seboj. Stari so bili od 20 do 84 let (v povprečju 44,4 leta). V večstanovanjski stavbi živi 13 udeležencev, v enostanovanjski stavbi z vrtom (samostojni hiši ali vrstni hiši) pa 14 . Od rojstva živijo na tem območju trije udeleženci, večina je priseljena (24) in živi tukaj od osem do 73 let. V skupnosti so večinoma družine z enim otrokom ali dvema, starejša udeleženka živi sama.

\subsection{Postopek}

Fokusne skupine so potekale v februarju 2013. V prostorih Osnovne šole dr. Vita Kraigherja smo izvedli tri skupine s po osem, devet in 10 udeleženci, ki so trajale najmanj poldrugo uro in največ dve uri in 10 minut. Razpravo je vodila moderatorka (raziskovalka) na osnovi pripravljenih vprašanj. Razpravo smo posneli z diktafonom, za kar smo predhodno od udeležencev dobili dovoljenje. Pogovor je bil v vseh fokusnih skupinah sproščen in dinamičen. Udeleženci so se razgovorili in izčrpno predstavili svoja mnenja, med njimi je potekala tudi interakcija na mnenja in stališč drugih. Ob koncu razprave $\mathrm{v}$ fokusnih skupinah je vsak posamezen udeleženec po metodi družbenoprostorskih obrazcev na zemljevidu označil točko, na kateri biva, območje, ki ga dojema kot sosesko, prijetna območja, ki so mu všeč oziroma nanja rad zahaja, in neprijetna območja, ki mu niso všeč oziroma nanja ne zahaja rad. Udeleženci so se dobro orientirali na zemljevidu in so označili zahtevano območje. $V$ procesu analize podatkov smo dobljene grafične odgovore vseh udeležencev združili na eno kartografsko podlago in dobili združeno skupino odgovorov po posameznih območjih (soseske, prijetna, neprijetna območja). Nato smo prikazali povprečje za posamezno vsebino tako, da smo območja, na katerih so se odgovorili zgostili in večkrat 
Preglednica 2: Doživljanje in uporaba javnih zelenih površin v treh fokusnih skupinah

\begin{tabular}{|c|c|}
\hline javne zelene in druge odprte površine & $\begin{array}{l}\text { vsi odgovori } \\
\text { (vsebina glede na zastavljena vprašanja) }\end{array}$ \\
\hline & Javne zelene površine so zelo pomembne za vsakodnevno preživljanje prostega časa. \\
\hline pomen & $\begin{array}{l}\text { Bližina in dobra urejenost zelenih in drugih odprtih površin pomeni večjo kakovost bivanja } \\
\text { v soseski. }\end{array}$ \\
\hline vrsta uporabe & $\begin{array}{l}\text { Zelene in druge odprte površine se večinoma uporabljajo za igro otrok, šport, rekreaci- } \\
\text { jo (predvsem tek in kolesarjenje), sprehode, sprehode s psom in za povezavo (peš, s kole- } \\
\text { som) do drugih delov mesta. }\end{array}$ \\
\hline urejenost zelenih površin & $\begin{array}{l}\text { Osrednje večje površine mestnih parkov in igrišč so dobro urejene, vendar slabo negovane. } \\
\text { Kot zelo slabo urejene so navedli manjše zelene površine med stanovanjskimi bloki, ki so } \\
\text { zelo zanemarjene in zapuščene, čeprav so pomembne za vsakdanjo uporabo in krajši oddih } \\
\text { prebivalcev stanovanjskih blokov. Veliko jim pomenijo ozelenjene ulice z drevoredi, ki jih } \\
\text { uporabljajo za sprehode in kolesarjenje. }\end{array}$ \\
\hline obstoj zelenih in drugih odprtih površin & $\begin{array}{l}\text { Zelenih in drugih odprtih površin je v soseski dovolj. Prebivalci navajajo, da doživljajo oko- } \\
\text { lje v soseski kot »zeleno sosesko«, hkrati pa poudarijo, da jih ob robovih obravnavanega } \\
\text { območja primanjkuje. }\end{array}$ \\
\hline $\begin{array}{l}\text { območja, ki so jim všeč in jih radi upora- } \\
\text { bljajo }\end{array}$ & $\begin{array}{l}\text { Osrednji park z otroškim igriščem pred osnovno šolo preučevanega območja, novejši me- } \\
\text { stni park na robu območja, sprehajalna in kolesarska pot, ki vodita okrog mesta, športna } \\
\text { igrišča in površine za rekreacijo. }\end{array}$ \\
\hline $\begin{array}{l}\text { moteči dejavniki ter območja, ki jim niso } \\
\text { všeč in jih neradi uporabljajo }\end{array}$ & $\begin{array}{l}\text { Slabo vzdrževanje zelenih površin, zanemarjenost in nedostopnost osrednjega mestnega } \\
\text { stadiona za prebivalce, nepreglednost, občutek nevarnosti na območju garaž ob stanovanj- } \\
\text { skih blokih, slabo vzdrževano območje storitvenih dejavnosti s tržnico, zapuščene stavbe, } \\
\text { neurejenost prostora okoli železniških delavnic ob železniški progi. }\end{array}$ \\
\hline $\begin{array}{l}\text { ovire v prostoru za uporabo javnih odprtih } \\
\text { površin }\end{array}$ & $\begin{array}{l}\text { Zelo prometne ulice, neurejeni železniški prehodi za pešce pri športnem parku, preveč za- } \\
\text { parkirane površine in ulice, zanemarjenost območja ob železniški progi, ovire na pločnikih } \\
\text { in prehodih za invalide in starše z otroškimi vozički. }\end{array}$ \\
\hline kaj pogrešajo oziroma kaj manjka & $\begin{array}{l}\text { Povezan sistem zelenih površin }{ }^{[7]} \text {, dodatne kolesarske poti, več drevoredov. V soseski eno- } \\
\text { družinskih hiš pogrešajo ploščad s košarkarskim košem, skupne zelenice s klopmi in prosto- } \\
\text { re za druženje sosedov. }\end{array}$ \\
\hline vključitev v urejanje prostora & Večinoma bi se prostovoljno vključili v urejanje odprtega prostora soseske. \\
\hline razno (kar so sami želeli dodati in povedati) & $\begin{array}{l}\text { Četrtna skupnost je premalo aktivna pri povezovanju z lokalno skupnostjo mesta. Zaradi } \\
\text { naraščajočega števila vlomov v stanovanja v zadnjih letih so posebej poudarili problemati- } \\
\text { ko varnosti bivanja v soseski. Kljub temu so povedali, da se na javnih odprtih površinah v } \\
\text { soseski večinoma počutijo varno, razen ponoči na območjih, na katerih je soseska premalo } \\
\text { osvetljena. }\end{array}$ \\
\hline
\end{tabular}

ponovili, označili kot povprečje odgovorov na kartografski podlagi. Tako smo dobili tri skupinske družbenoprostorske obrazce za vsako posamezno vsebino. Na sliki 4 je prikazano povprečje odgovorov vseh udeležencev opredelitve prijetnih in neprijetnih območij skupaj. S prikaza lahko razberemo, kje so najpomembnejša območja in kje se prekrivajo (hkrati prijetno in neprijetno območje).

\section{Rezultati in razprava}

Rezultati empirične raziskave so vsebinski in metodološki. Vsebinski rezultati so pokazali, katere dejavnike in kako jih lahko upoštevamo pri načrtovanju javnega odprtega prostora. Metodološki rezultati so razkrili uporabnost kombinacije metode fokusnih skupin in družbenoprostorskih obrazcev pri odkrivanju dejavnikov, pomembnih za spoznavanje doživljanja, uporabe in načrtovanje prostora. Rezultati obeh metod se dopolnjujejo in ne izključujejo. Ugotovitve, pridobljene v fokusnih skupinah (prijetna in neprijetna območja), so potrdili družbenoprostorski obrazci.

Udeleženci so posredovali uporabne podatke, mnenja, stališča, predloge in kritike obstoječega stanja, ki bi jih načrtovalci prostora lahko upoštevali pri prenovi odprtih javnih površin na obravnavanem območju. Izsledki rezultatov fokusnih skupin (preglednica 2) so poudarili pomen, uporabo in stanje teh ter odnos prebivalcev do javnih zelenih površin pri vsakodnevnem preživljanju prostega časa. Prebivalci so izrazili zadovoljstvo z obsegom zelenih površin, ne pa tudi z njihovo razporeditvijo, ki je preveč centralizirana. Navedli so, da so osrednje površine dobro urejene, vendar slabo negovane, manjše površine, predvsem med stanovanjskimi bloki, pa so precej zanemarjene. Opredelili so ovire v prostoru, ki so moteče za uporabo odprtih površin, navedli pomanjkljivosti in dejavno- 

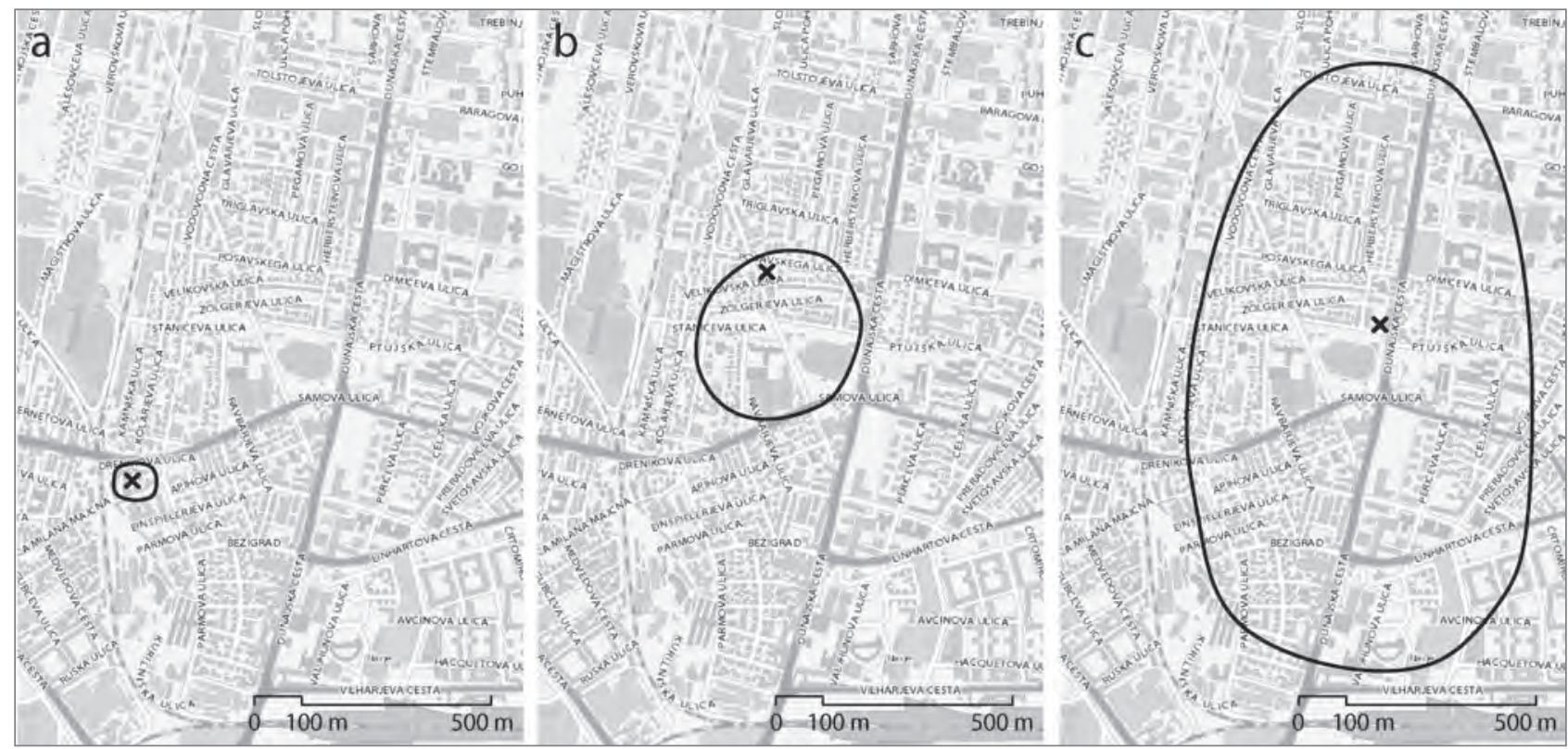

Slika 3: Primeri treh skrajnih odgovorov prebivalcev o soseski na družbenoprostorskem obrazcu - oznaka kraja bivališča (oznaka x) in soseske (obkroženo): (a) primer soseske kot majhnega območja okrog bivališča, (b) primer soseske kot srednje velikega območja okrog bivališča in (c) primer zelo velikega območja soseske (ilustracija: Nataša Bratina Jurkovič)

sti, ki jih pogrešajo, ter izrazili pripravljenost za sodelovanje pri urejanju prostora. Izčrpno in temeljito sodelovanje udeležencev v fokusnih skupinah je pokazalo, da prebivalce zelo zanima, $\mathrm{v}$ kakšnem stanju so javne zelene površine in odprti prostori in kako so urejeni. Udeleženci, ki imajo ob hišah vrtove, so dejali, da jih sicer vsak dan uporabljajo za sprostitev, kljub temu pa za druženje z drugimi, za šport ali rekreacijo uporabljajo tudi javne skupne odprte površine. Ker je takih površin v soseskah z enostanovanjskimi stavbami običajno premalo ali jih sploh ni, so navajali, da jih pogrešajo.

Med odgovori je tudi nekaj pomembnih razlik v stališ̌cih udeležencev, čeprav je metoda namenjena predvsem pridobivanju skupnih pogledov prebivalcev. Razlikovala so se predvsem stališča mlajših in starejših udeležencev. Mlajši udeleženci menijo, da je območje preveč mirno ter da nima središča zbiranja in delovanja. Navedli so, da pogrešajo mestni trg z lokalom in $s$ pekarno ter podobnimi dejavnosti (mestni utrip), na katerem bi se lahko razvila osrednja točka srečevanja z drugimi stanovalci in s prijatelji. Starejši so poudarili prav nasprotno, da si želijo več miru in zelenega okolja ter več košev za smeti in klopi ob sprehajalnih poteh, na katerih bi se lahko večkrat spočili. Razlikovala so se tudi mnenja udeležencev $z$ družinami $s$ predšolskimi otroki in $s$ starejšimi otroki, ki že samostojno uporabljajo odprte prostore. Tisti z mlajšimi otroki so navedli, da je raznolikost in urejenost površin za igro otrok ustrezna, razen da so ponekod ob blokih površine zanemarjene in da igrala niso vzdrževana. Udeleženci $s$ starejšimi otroki pa so navajali pomanjkanje manjših površin z urbano opremo za druženje otrok (npr. ploščad s košem za košarko, miza za namizni tenis, sistem več klopi skupaj za druženje ipd.). Starši, ki imajo tako majhne otroke, da jih vozijo na sprehode z vozičkom, in udeleženka, ki za gibanje uporablja invalidski voziček, so opozorili na to, da odprte površine večinoma sploh niso urejene tako, da bi bile prilagojene gibalno oviranim osebam. Omenili so tudi nepregledne in nezavarovane prehode za pešce, neurejen prehod čez železniške tire (slika 10), ki pomeni za invalide nepremagljivo oviro, zaradi katere ne morejo na drugo stran proge, kjer so športni park in sprehajalne poti. Pokazale so se nekatere razlike pri udeležencih, ki živijo v naselju enostanovanjskih hiš z vrtovi, in udeležencih, ki živijo v naselju večstanovanjskih stavb oziroma blokov. Prebivalci iz enodružinskih hiš pogrešajo skupne javne površine za druženje sosedov in večjih otrok (najstnikov). Menijo, da njihovi zasebni vrtovi ne morejo zadovoljiti potreb po spontanem skupnem druženju otrok in odraslih v soseski, ki bi jih želeli izvajati na javnih površinah v soseski v neposredni bližini doma.

Tudi Skifter Andersen (2011) v okviru raziskave o preferencah do okolice in lokacije doma ugotavlja, da se razlikujejo prevladujoči dejavniki pri mladih, družinah $\mathrm{z}$ otroki in starejših. Navaja, da je prevladujoč dejavnik pri mladih bližina socialnih mrež, mestnega utripa in prevoza. Nasprotno pa si starejši ne želijo bližine socialnih mrež, ampak narave in miru. Njegove ugotovitve iz raziskave, opravljene med prebivalci na Danskem, se ujemajo z mnenji prebivalcev naše raziskave v Ljubljani.

Mnenja in stališča prebivalcev, izražena v okviru fokusnih skupin, so olajšala razlago pridobljenih podatkov $z$ družbenoprostorskimi obrazci. Kar so udeleženci poudarili v pogovoru, so tudi označili na zemljevidu oziroma je bilo zajeto v njihovem družbenoprostorskem obrazcu. Večina udeležencev je označila 


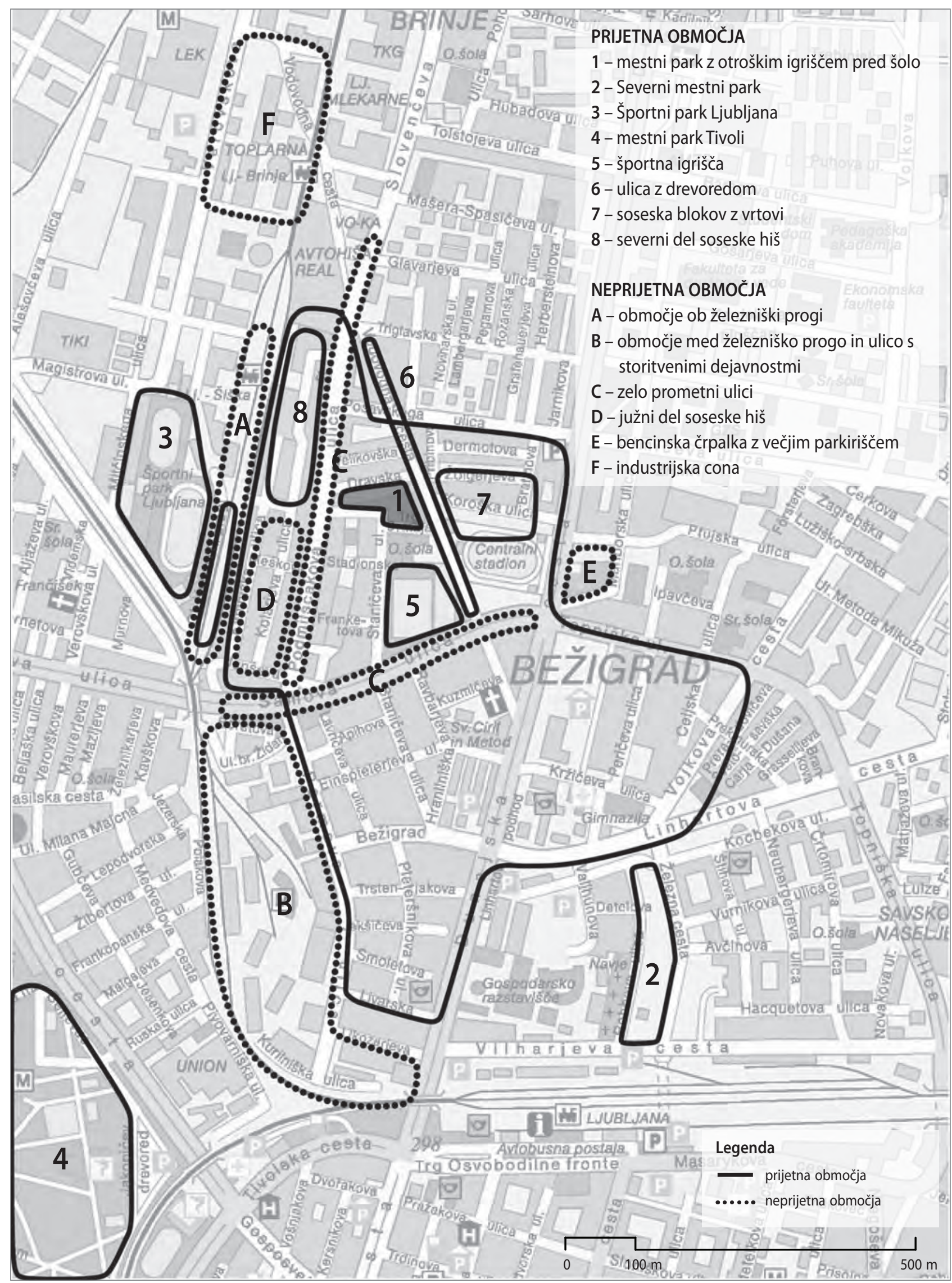

Slika 4: Prikaz prijetnih območij, na katera prebivalci radi zahajajo, in neprijetnih območij, na katera ne hodijo radi - povprečje vseh odgovorov (ilustracija: Nataša Bratina Jurkovič). 
vsa zahtevana območja. Zanimivo je, da šest udeležencev ni označilo nobenega neprijetnega območja, ampak samo prijetna območja in območje soseske, z utemeljitvijo, da neprijetnih območij ni. Nekaj udeležencev je označilo tudi območja zunaj soseske oziroma zunaj območja zemljevida (s črto in puščico), na katera radi zahajajo (park Tivoli, hrib Rožnik, rekreativni park Mostec, hrib Šmarna gora). Gre za naravna zelena območja z vzpetinami, ki so med meščani priljubljena za sprehode in rekreacijo.

\subsection{Zaznava območja soseske}

Iz primerov, predstavljenih na sliki 3, lahko vidimo, da udeleženci območje soseske zaznavajo zelo različno. Nekateri območje soseske dojemajo le kot ožje območje okrog bivališča - slika 3a (premer $50 \mathrm{~m}-100 \mathrm{~m}$; število odgovorov $=10$ ), drugi pa pojmujejo sosesko v širokem obsegu skoraj celotnega območja obravnave ali celo širše - slika 3c (premer 700 m-1300 m; število odgovorov $=4$ ). Nekateri označujejo sosesko kot ovalno območje okrog točke bivališča, drugi pa na zemljevidu obravnavanega območja natančno označijo določene ulice in območja, ki so zanje pomembni. Dva udeleženca sta označila za sosesko le območje v bližini doma, ki jima je hkrati tudi prijetno in na katero rada zahajata. Tako se območje soseske in prijetno območje popolnoma prekrivata. Večina udeležencev zaznava sosesko kot srednje veliko območje okrog doma, v radiju, v katerem se še poznajo in družijo $s$ sosedi - slika $3 b$ (premer $250 \mathrm{~m}-450 \mathrm{~m}$; število odgovorov $=13$ ). Opredelitev soseske in njenega delovanja ima pomembno vlogo pri doživljanju in uporabi prostora prebivalcev. Prebivalci se s sosesko čutijo povezani, so bolj osebno odgovorni in kritični do dogajanja na območju, ki ga zaznavajo kot svojo sosesko, kot v drugih delih širšega območja vsakdanje rabe. Jane Jacobs (2009) opredeljuje pomen mestnih sosesk in navaja, da je večina prebivalcev večjih mest v vsakdanjem življenju zelo odvisna od delovanja svoje soseske, obenem pa svoje potrebe lahko zadovoljuje na celotnem območju mesta.

\subsection{Prijetna območja}

Prijetna območja so dobro zastopana in udeleženci so jih označili v velikem številu in obsegu. Celotno območje obravnave so udeleženci večinoma ocenili kot prijetno za bivanje in uporabo. Prijetna območja so označevali kot več manjših območij ali zelo na široko, tako da so zajemala vsa priljubljena območja, ki jih radi uporabljajo. Če primerjamo vsa pozitivna območja (slika 4), ki jih je označila večina prebivalcev na družbenoprostorskih obrazcih, lahko vidimo, da je za vse udeležence prijetno območje osrednjega parka z otroškim igriščem pred Osnovno šolo dr. Vita Kraigherja- oznaka 1 (za fotografski prikaz območja glej sliko 5). Označili so še nekaj posameznih območij (slika 4): večji mestni parki, priljubljeni za igro, sprehode in rekreacijo (oznaki 2 in 4), ulica z drevoredom (oznaka 6) in območje športnih igrišč (oznaki 3 in 5). Nekatera prijetna območja se prekrivajo z označenimi neprijetnimi območji.
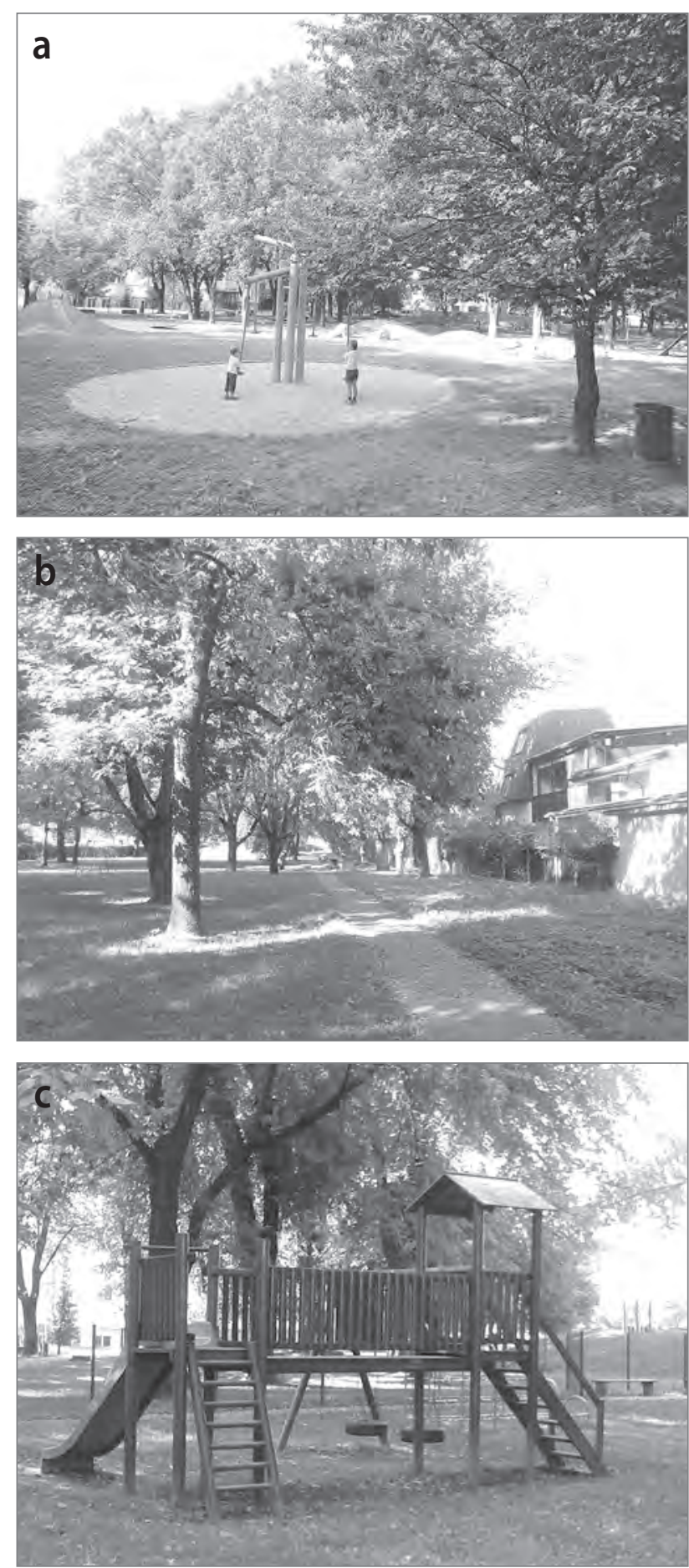

Slika 5: Park z otroškim igriščem, v raziskavi opredeljen kot osrednja najbolj priljubljena in obiskana zelena površina na obravnavanem območju šolskega okoliša; (a) otroško igrišče, (b) sprehajalna pot v parku in (c) igrala v parku (Trg 9. maja 1, Bežigrad, foto: Nataša Bratina Jurkovič). 


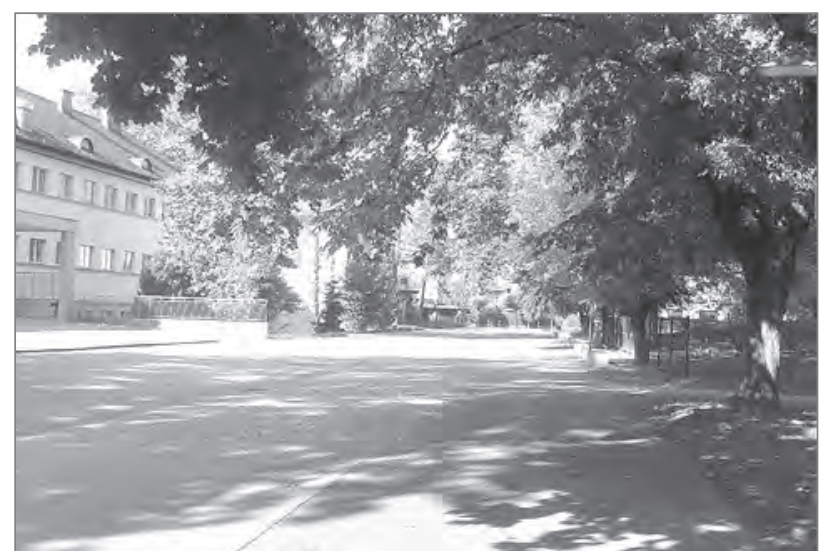

Slika 6: Ploščad pred osnovno šolo, ki deluje kot trg, poleg osrednjega parka z otroškim igriščem (Trg 9. maja 1, Bežigrad, foto: Nataša Bratina Jurkovič).

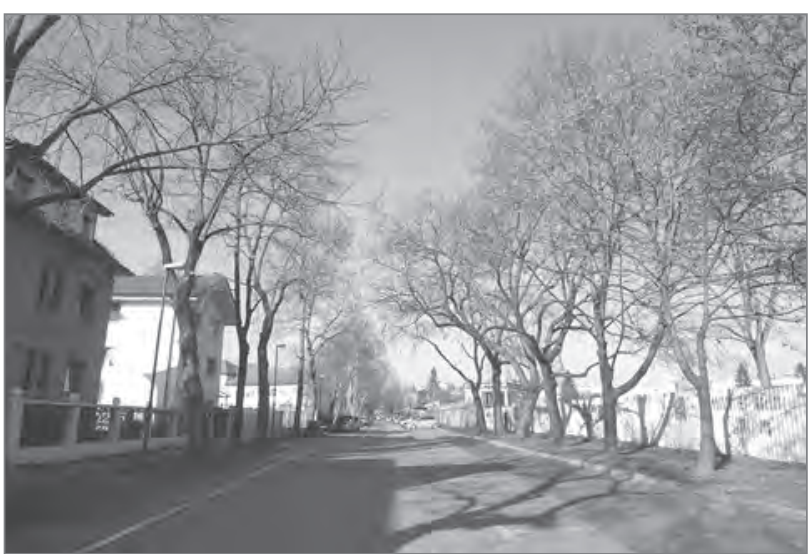

Slika 7: Ulica z drevoredom in s kolesarsko potjo, ki se uporablja kot osrednja povezava do centra mesta (Vodovodna ulica, foto: Nataša Bratina Jurkovič).

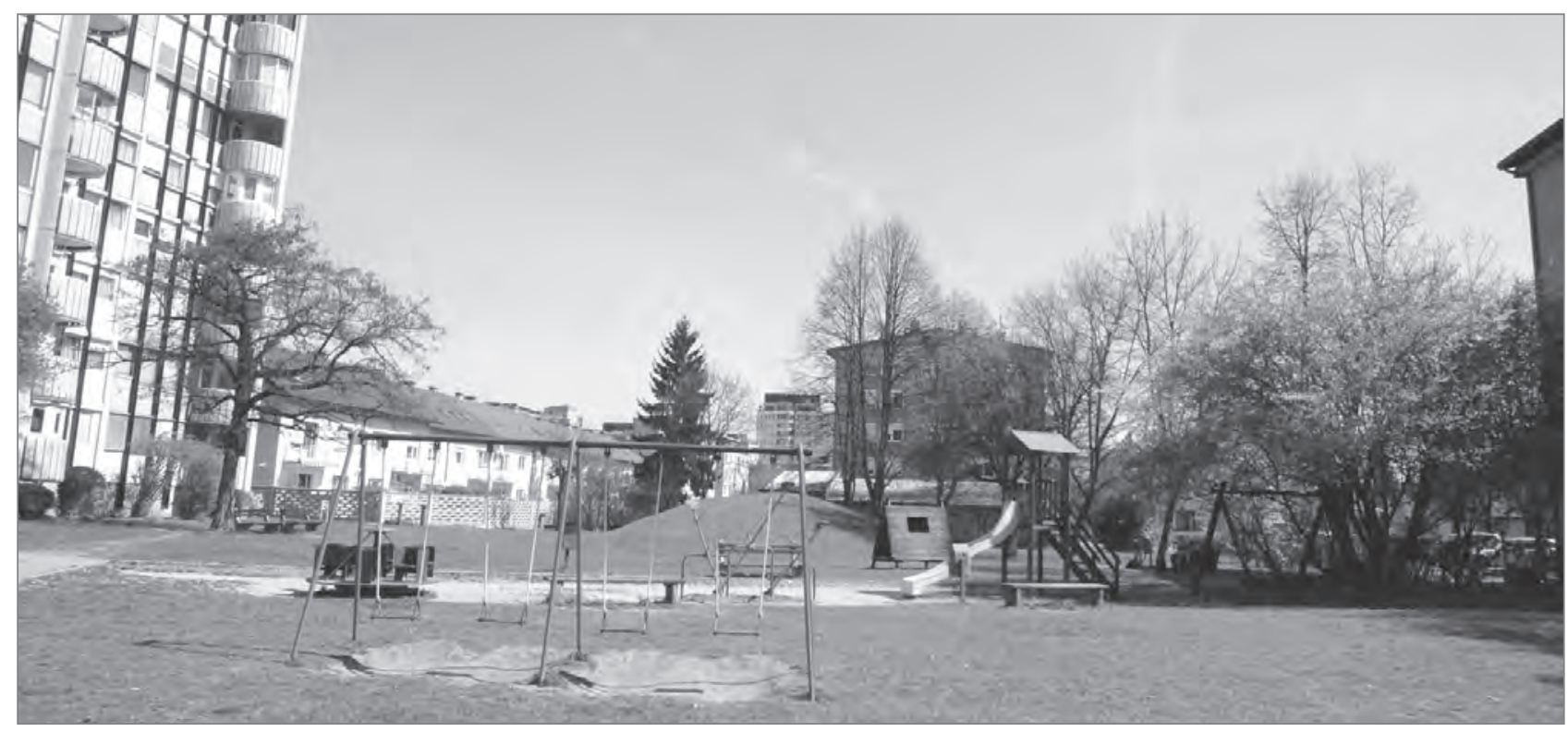

Slika 8: Manjša, slabše urejena zelenica z igrali (Glavarjeva ulica, foto: Nataša Bratina Jurkovič)

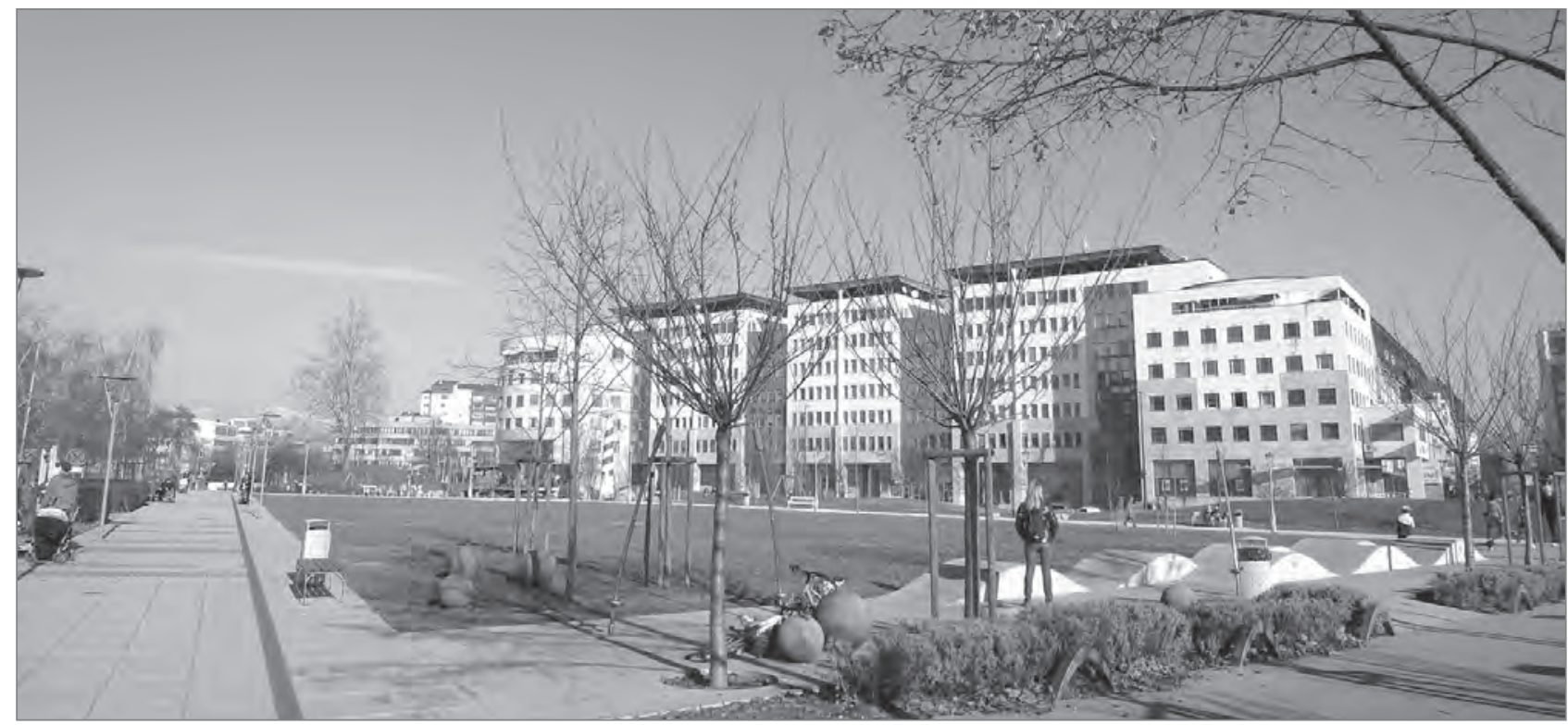

Slika 9: Sodobni mestni park z otroškim igriščem in ograjenim območjem za pse (Severni mestni park, foto: Nataša Bratina Jurkovič) 


\subsection{Neprijetna območja}

Neprijetna območja so razporejena na določenih mestih in ne po vsem območju obravnave. Večinoma so bili prebivalci tudi pri označevanju teh območij enotni (slika 4). Označili so jih vzdolž vse železniške proge - oznaka A (za fotografski prikaz območja glej sliko 11) in oznaka B (za fotografski prikaz območja glej sliko 13) -, ki obdaja obravnavano območje raziskave, in nekatera druga manjša območja (slika 4), kot so: zelo prometni ulici (oznaka C), bencinska črpalka z zanemarjenim parkiriščem (oznaka E), industrijsko območje $s$ toplarno (oznaka F; za fotografski prikaz območja glej sliko 12). Nekaj udeležencev ni označilo nobenega neprijetnega območja, ker ga ne zaznavajo. Zanimivo je, da se območje ob železniški progi, južni del (oznaka A; za fotografski prikaz območja glej sliko 11b), pojavi dvakrat, in sicer kot neprijetno in prijetno območje. To pomeni, da ima območje potencial, vendar bi ga bilo treba urediti v skladu s predlogi prebivalcev. Drug tak primer je južni del stanovanjske soseske enodružinskih hiš (oznaka D) in širše označeno območje, na katerem je vsa navedena soseska zajeta v večje prijetno območje. Obenem je soseska enodružinskih hiš razdeljena na dva dela: severni del je označen kot prijeten (oznaka 8), južni pa kot neprijeten (oznaka D). Do tega je prišlo, ker je označeno prijetno območje v soseski enodružinskih hiš lepše urejeno, ima manjši park z otroškim igriščem pred bloki, kavarno in kliniko za male živali ter zaradi slepe ulice bolj umirjen promet, tako da je namenjeno samo dovozu. Medtem ko je spodnji del soseske enodružinskih hiš (oznaka D) programsko bolj pust in ima nekaj stavb, ki so zanemarjene in celo razpadajo, ima pa tudi stalni pretočni motorni promet.

$\mathrm{V}$ povezavi z odgovori udeležencev $\mathrm{v}$ fokusnih skupinah ugotavljamo, da sta število ter velikost označenih prijetnih in neprijetnih območij na spoznavnem zemljevidu odvisna od tega, koliko je udeleženec aktiven ter koliko uporablja zelene in druge odprte površine v svoji stanovanjski soseski. Udeleženci, ki veliko uporabljajo odprte prostore za vsakdanjo sprostitev, gibanje in rekreacijo, poznajo obravnavano območje bolje in so na zemljevidu označili veliko različnih območij. Udeleženci, ki zelene in druge odprte površine v stanovanjski soseski zelo malo uporabljajo ali pa jih sploh ne, so označili zelo majhna območja okrog svojega doma, ker širšega območja ne poznajo.

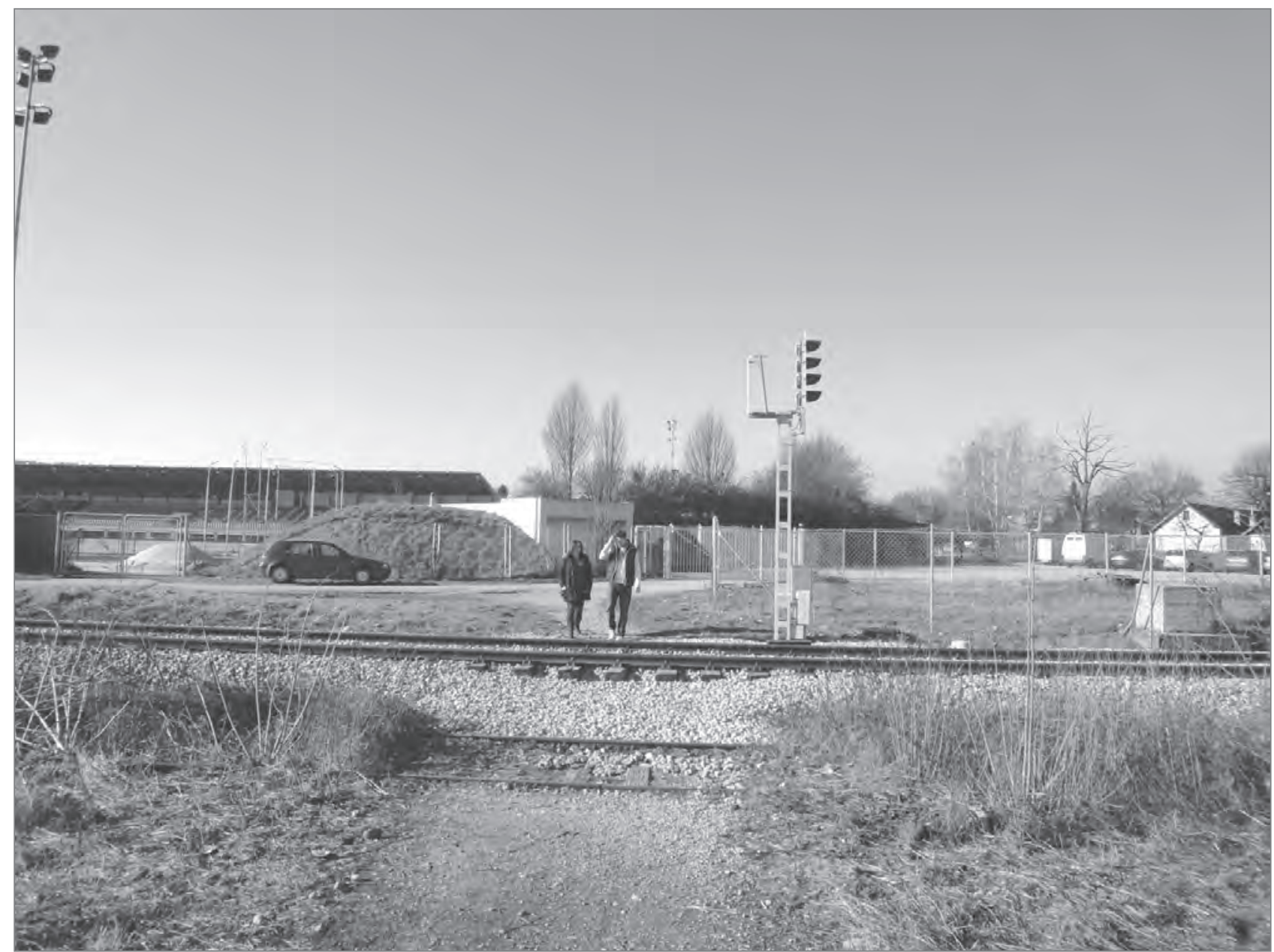

Slika 10: Neurejen železniški prehod za pešce pri Športnem parku Ljubljana (foto: Nataša Bratina Jurkovič) 

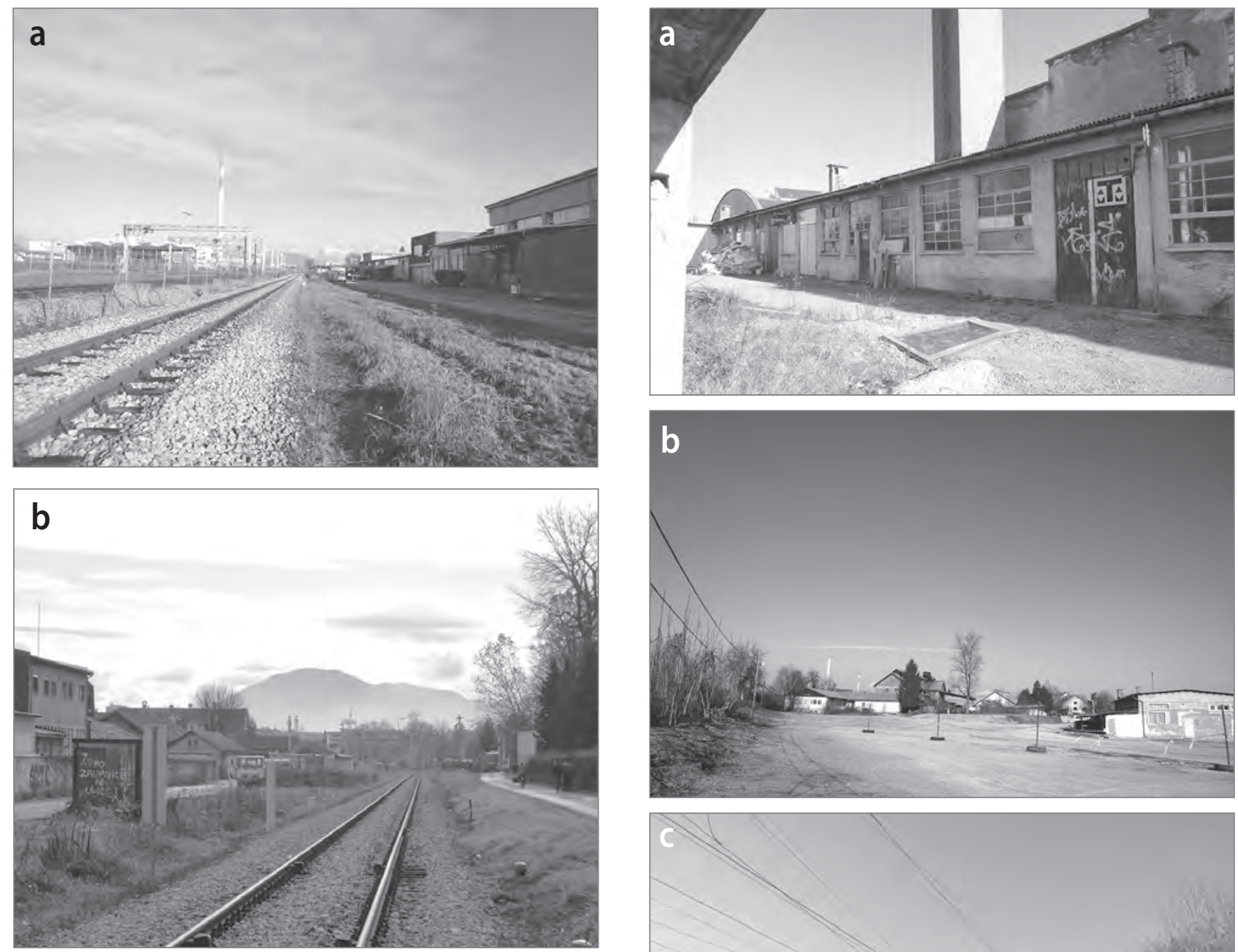

Slika 11: Degradirano in zanemarjeno območje ob železniški progi v smeri Kamnika, označeno kot neprijetno: (a) pogled proti severu na Kamniške-Savinjske Alpe in (b) pogled proti jugu (foto: Nataša Bratina Jurkovič).
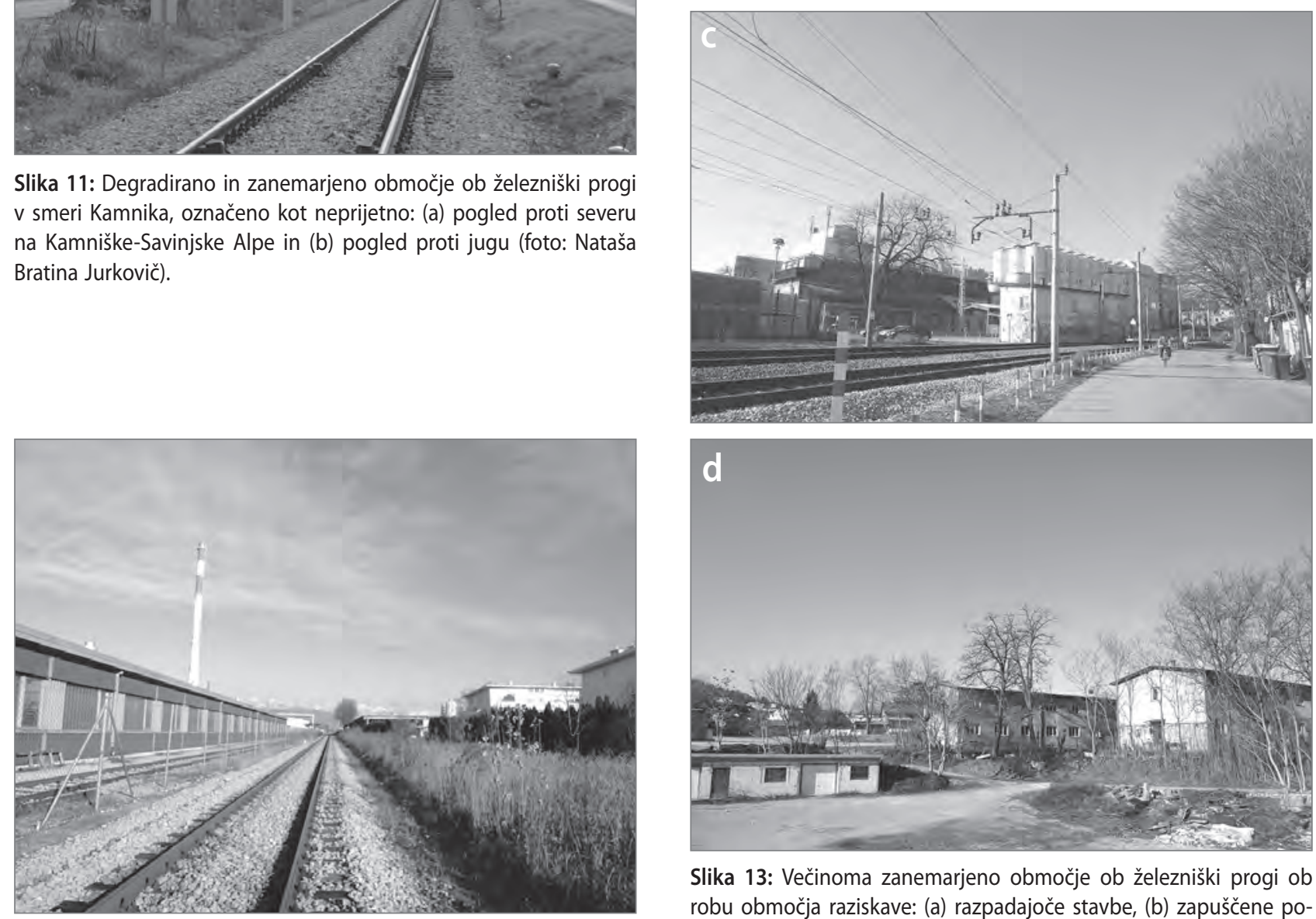

Slika 13: Večinoma zanemarjeno območje ob železniški progi ob robu območja raziskave: (a) razpadajoče stavbe, (b) zapuščene površine, (c) pot ob progi in (d) zanemarjene površine z odpadki (foto: Nataša Bratina Jurkovič).

Slika 12: Industrijsko območje s toplarno (foto: Nataša Bratina Jurkovič) 


\subsection{Usmeritve za prostorsko načrtovanje}

Predstavljeni izsledki raziskave kažejo, da je javni odprti prostor v stanovanjskih soseskah zelo pomemben za prebivalce. Raziskava ponazarja, kako se zaznava prijetnih in neprijetnih delov soseske, način uporabe, stanje in urejenost zelenih in drugih površin, opredeljeni moteči dejavniki in ovire v prostoru izražajo v vsakdanji uporabi prebivalcev. Nekaj rezultatov je pričakovanih, na primer zaželenost prisotnosti in urejenosti zelenih površin ter programska pestrost vseh odprtih površin. Nekateri dejavniki so v vzajemni soodvisnosti - če so odprti prostori dobro načrtovani in oblikovani po meri prebivalcev, so zelo obiskani in se uporabljajo, če pa so zanemarjeni, degradirani ali omejeni z ovirami v prostoru, so prazni, vendar pa izražajo potencial za prenovo in izboljšanje stanja.

$\mathrm{Na}$ osnovi dobljenih rezultatov smo oblikovali nekaj usmeritev, ki so kot predlogi lahko uporabne pri načrtovanju javnega odprtega prostora v stanovanjskih soseskah mesta:

- Bližina in dobra urejenost zelenih in drugih odprtih površin pomeni za prebivalce boljšo kakovost bivanja $\mathrm{v}$ soseski.

- Zelene in druge odprte površine prebivalci uporabljajo za zelo različne dejavnosti, zato je treba načrtovati raznoliko programsko vsebino. Zelo pomembni so drevoredi ob ulicah kot zeleni koridorji, ki jih prebivalci izbirajo za pešpoti in kolesarske poti. Omogočanje raznolikosti rabe pomeni za prebivalce prednost in privlačnost za uporabo odprtega prostora mesta.

- Načrtovalci in investitorji morajo biti pozorni na kakovostno urejanje manjših in razdrobljenih zelenih in drugih odprtih površin v bližini stanovanjskih stavb, ne pa samo načrtovati večjih osrednjih površin (kot so parki, otroška igrišča, športna igrišča).

- Treba je enakomerno razporediti zelene površine na stanovanjskih območjih in jih povezati v sistem, da lahko uporabniki neovirano prehajajo $\mathrm{z}$ enega na drugo območje.

- Območja, ki so jim všeč in na katera radi prihajajo, so zelo kakovostno urejena in dobro vzdrževana.

- Območja, navedena kot neprijetna, so moteči dejavniki v prostoru ter potrebujejo čimprejšnjo prenovo in ureditev.

- Ovire v prostoru za uporabo odprtih površin so predvsem prometne ulice, večja prometna križiššca, neurejeni cestni in železniški prehodi, nepregledna območja garaž in parkirišč ter zanemarjeni degradirani urbani deli.

- Vsebine, ki jih prebivalci pogrešajo in bi jih bilo dobro upoštevati pri prenovi ali nadgradnji sosesk, so predvsem povezava zelenih površin v mrežo ali sistem in potreba po skupnih javnih površinah za druženje pri prebivalcih enostanovanjskih hiš, čeprav imajo zasebne vrtove.

- Za prebivalce je varnost v soseski pomembna, zato si želijo takih ureditev, ki ponoči zagotavljajo dobro osvetljenost na glavnih pešpoteh in kolesarskih poteh.

- Prebivalci območje svoje soseske večinoma dojemajo kot srednje veliko območje okrog doma, v katerem še poznajo sosede in se družijo u njimi. Na to območje so navezani in zanje je zelo pomembno, dojemajo ga za svoje oziroma jim predstavlja identiteto.

- Prebivalci opozarjajo, da je sodelovanje mestne četrti s soseskami zelo pomembno. Menijo namreč, da bi sami lahko pomagali pri reševanju problemov iz svojih stanovanjskih sosesk in tako vplivali na mestno politiko. Sedanje sodelovanje ocenjujejo kot zelo pomanjkljivo.

\subsection{Skladnost rezultatov dveh metod}

Rezultati kažejo, da so podatki, pridobljeni s posamezno metodo, med seboj skladni. To je lahko posledica zaporedne izpeljave obeh postopkov, pri čemer je drugi (družbenoprostorski obrazci) sledil prvemu, v katerem je bila tematika vsebinsko obravnavana. Tudi ugotovitve drugih raziskovalcev kažejo (na primer Lee, 1976; Lynch, 2010; Polič, 2002, ter Kim in Penn, 2004), da se prostorske zakonitosti realnega okolja in prostorske zakonitosti, izražene na spoznavnih zemljevidih, povezujejo in so med seboj večinoma skladne. Drugi raziskovalci so metodi posamično uporabljali za raziskave s področja uporabe in doživljanja prostora, vendar nismo zasledili, da bi ju kdo uporabil skupaj. James Potter in Rodrigo Cantarerro (2006) navajata, da sta v raziskavi uporabila fokusne skupine kot predhodno metodo, $\mathrm{z}$ rezultati teh pa sta pozneje lažje oblikovala in prilagodila izvedbo vprašalnika. Nekateri avtorji (Kim in Penn, 2004; Kuipes idr., 2006, ter Lynch, 2010) navajajo uspešno uporabo različnih metod za raziskovanje spoznavnih zemljevidov (ang. cognitive maps), ki so tudi grafične metode s prostorsko opredelitvijo odgovorov preizkušancev na kartografskih kartah ali skice prostora, narisane po spominu preizkušancev.

$\mathrm{Z}$ raziskavo smo ugotovili, da značilnosti prostora, kot so ulice $\mathrm{z}$ različno gostoto prometa, železniška proga, parkirišča, prisotnost naravnih elementov, preglednost ali nepreglednost prostora, dostopnost, vzdrževanost ali zanemarjenost, elementi urbane opreme in druge fizične lastnosti v bivalnem okolju, vplivajo na zaznavanje, doživljanje in uporabo odprtega javnega prostora mestne soseske. Ti dejavniki lahko v odprtem prostoru delujejo kot ovire, s čimer zavirajo njegovo uporabo, ali pa kot spodbujevalci, kar pospešuje njegovo uporabo. Naravni elementi in kakovostno urejeni odprti prostori imajo pomembno vlogo pri občutku prebivalcev za skupnost. Programsko bogato zasnovane zelene površine spodbujajo prebivalce $\mathrm{k}$ uporabi, s čimer se povečuje verjetnost socialnih interakcij (Kim in Kaplan, 2004). Parki in parkom podobne javne površine so odvisni od obiskanosti in priznanja prebivalcev (Jacobs, 2009). Jane Jacobs navaja, da prav ljudje, ki 
uporabljajo parke, s svojim obiskom določajo, ali so parki priljubljeni ali nepriljubljeni. Po njenem mnenju so še posebej » parki v soseskah neposredno in izrazito odvisni od vpliva in odnosa soseske do njih « (prav tam: 110). Zavedati se moramo, da načrtovalci z ustrezno razporeditvijo prostorskih elementov $\mathrm{v}$ odprtem prostoru omogočajo izvajanje dejavnosti ter tako vplivajo na uporabo, doživljanje in zaznavanje prebivalcev odprtega prostora sosesk.

Razprava v fokusnih skupinah kaže, da so prostorski elementi, ki razdružujejo in otežujejo stike ter uporabo zelenih in drugih odprtih površin, predvsem prometnice, obremenjene z motornim in železniškim prometom, nezavarovani železniški prehodi in gosto zaparkirane parkirne površine. Slabo vidni in nepregledni deli, kot so območja garaž in podhodi, so lahko zaznani tudi kot nevarni, neprijetni zaradi zanemarjenosti in mogoče prisotnosti vandalizma. Prostorski elementi, ki delujejo kot spodbujevalci, so predvsem naravni elementi (drevesa, zelenice) in elementi urbane opreme, ki omogočajo počitek, sedenje, klepet, razgled in hkrati zasebnost, možnost raziskovanja, ter elementi za igro in športne aktivnosti. Nico Larco idr. (2012) navajajo, da je v mestih treba zagotoviti pešcem prijazno oblikovanje pri načrtovanju odprtih prostorov, saj $s$ tem omogočamo dobro obiskanost in » urbano živahnost «.

William Sullivan idr. (2004) menijo, da je prisotnost dreves in travnih površin povezana $\mathrm{z}$ bolj množično uporabo odprtih prostorov. Ugotavljajo, da značilnosti odprtega prostora vplivajo na družbene stike med sosedi in dokazujejo, da imajo elementi narave pomembno vlogo pri ustvarjanju vitalnih prostorov stanovanjskih sosesk. Spodbujevalni prostorski elementi omogočajo nedejavno in dejavno zaposlitev, sprostitev, udobje in varnost. Tudi Takemi Sugiyama idr. (2009) navajajo, da sta prijetnost in varnost odprtih prostorov pomembni lastnosti za zadovoljstvo bivanja prebivalcev v urbanih soseskah. Anne R. Kearney (2006) je poudarila, da na zadovoljstvo bivanja prebivalcev vpliva bližina javnih skupnih odprtih prostorov z vključenimi elementi narave, saj jim zagotavlja možnost vsakdanje uporabe in pogled na naravo od doma. Manj ko je prostorskih dejavnikov, ki pomenijo ovire v prostoru, in več ko je prostorskih elementov kot spodbujevalcev v prostoru, več bo druženja med prebivalci in uporabniki in višja bo kakovost bivanja $\mathrm{v}$ soseski. Razmerje med obojim naj bi kot nekakšen spodbujevalni ali zaviralni količnik izražalo vpliv na bivalno okolje kot dejavnik socialne interakcije in počutja. Obenem se je treba zavedati, da ima kakovostno urejen odprti prostor z zelenimi površinami $\mathrm{v}$ urbanih stanovanjskih soseskah pomembno vlogo pri odločanju ljudi za nakup stanovanja. Krystal Noiseux in Mark E. Hostetler (2010) priporočata načrtovalcem, naj upoštevajo vključenost zelenih površin $\mathrm{v}$ oblikovanje odprtega prostora sosesk kot pomemben dejavnik pri izbiri in odločitvi za nakup stanovanja. Naložbe mest $\mathrm{v}$ javni odprti prostor stanovanjskih sosesk imajo pomembno vlogo pri večanju kakovosti bivanja prebivalcev (Pallares-Barbera idr., 2011, in Wu, 2013).

Na podlagi naše raziskave in drugih tovrstnih raziskav je mogoče pripraviti smernice za načrtovalce, prostorske uradnike in investitorje za izboljšavo in prenovo obravnavanega območja. Raziskava je pokazala, kje so ključne točke in najbolj priljubljena ter obiskana območja, kje so ovire in moteči dejavniki za uporabo javnih odprtih površin, katere so težave, kaj ljudje pogrešajo ter kaj bi radi v svoji soseski spremenili in izboljšali.

\section{Sklep}

V prispevku smo predstavili način pridobivanja podatkov o doživljanju in uporabi mestnega odprtega prostora pri prebivalcih, opredelili dejavnike, ki pomembno vplivajo na zadovoljstvo prebivalcev, in nakazali možnosti vključevanja ključnih ugotovitev v usmeritve za urbanistično načrtovanje. Kot se je izkazalo, je uporaba kombinacije metode fokusnih skupin in pridobivanja družbenoprostorskih obrazcev smiselna ter pomeni nadgradnjo obeh metod $\mathrm{v}$ smislu zanesljivosti rezultatov in njihove prostorske opredelitve na zemljevidu. Raziskava je prinesla številne uporabne informacije, potrebne za načrtovanje bivalnega okolja mesta, kot so potreba po načrtovanju več drevoredov ob ulicah, pomen vzdrževanja in obnavljanja manjših zanemarjenih zelenih površin $\mathrm{z}$ igrali in $s$ klopmi tudi na robovih sosesk in ne samo v večjih mestnih parkih, povezava zelenih površin $\mathrm{v}$ sistem $\mathrm{z}$ navezavami $\mathrm{v}$ druga večja zelena območja mesta in vzpostavitev zelenih koridorjev ob zdaj zanemarjenem železniškem območju. Kritične so izvedbe v odprtem prostoru, ki ne upoštevajo rešitev za dostop gibalno oviranih oseb. Prebivalci naselja enostanovanjskih hiš kljub svojim vrtovom pogrešajo $\mathrm{v}$ soseski manjše javne zelene površine $\mathrm{z}$ igrali in $s$ klopmi ter površine za druženje. Območja, ki so bila opredeljena kot neprivlačna in predstavljena kot zanemarjena, so prav gotovo potrebna prenove in nadgradnje za potrebe preživljanja prostega časa. Označena privlačna območja so se (skupaj z utemeljitvami iz pogovora $v$ fokusnih skupinah) izkazala kot območja, ki delujejo kot osrednja območja dogajanja ter množične uporabe prebivalcev in zunanjih obiskovalcev. Prebivalci svojo sosesko večinoma zaznavajo kot srednje veliko območje okrog svojega doma, v radiju, v katerem še poznajo sosede in se družijo z njimi. Do tega prostora so $\mathrm{v}$ razpravi običajno tudi najbolj kritični in za izboljšave imajo tudi največ predlogov, ker je to okolje njihovega vsakodnevnega bivanja in ga najbolje poznajo.

Če se v mestih začnejo izvajati načrti prenove brez povezanosti $s$ prebivalci in $\mathrm{z}$ drugimi uporabniki v soseski ali širšem območju skupnosti, obstaja tveganje neustreznega in celo vsebinsko slabega načrtovanja programa. Velikopotezno poseganje načr- 
tovalcev v obstoječi odprti prostor je lahko za prebivalce zelo občutjivo in običajno sproža pri njih odpor, ker niso vključeni $\mathrm{v}$ ustvarjalno sodelovanje za preoblikovanje njihovega odprtega bivalnega območja, lahko bi rekli »domačega dvorišča «. $\mathrm{Na}$ podlagi raziskave ugotavljamo, da prebivalci tako dojemajo pripadajoči odprti prostor $\mathrm{v}$ stanovanjskih soseskah. Za resničen vpogled $\mathrm{v}$ to, kar želi skupnost, je potrebna celovita analiza in stik z lokalnimi prebivalci. Prostor je treba spoznavati z vseh vidikov, ob različnih letnih časih ali urah dneva in opazovati, kako poteka vsakdanje življenje v prostoru, in ugotoviti, kaj o tem menijo uporabniki prostora. Nikakor ne smemo zanemarjati njihovega mnenja z utemeljitvijo, da niso strokovnjaki. Pomembno je, da razvojni načrti mest, odprtega javnega prostora in še posebej odprtega prostora stanovanjskih sosesk ne nastajajo samo v pisarnah, ločeno od uporabnikov, ampak v sodelovanju z njimi. Investitorji in načrtovalci stanovanjskih območij bi se morali zavedati, da je kakovostno in zanimivo oblikovan odprti prostor z zelenimi površinami na območju stanovanj dodatna vrednost $\mathrm{k}$ osnovni vrednosti stanovanja, ki jo lahko tržijo, in pogosto odločujoč dejavnik pri končni odločitvi za nakup stanovanja.

Na podlagi pridobljenih spoznanj ugotavljamo, da je mogoče interes prebivalcev in javnosti za odprt prostor mesta usmeriti v ustvarjalno sodelovanje pri urejanju prostora in snovanju novih aktivnosti. Hkrati je vključevanje javnosti oziroma prebivalcev $\mathrm{v}$ zgodnjih fazah priprave strokovnih podlag za načrtovanje smiselno za ustvarjanje kakovostnih in uporabnih odprtih javnih prostorov. $S$ tovrstnimi raziskavami in analizami prostora dobimo rezultate, ki so lahko dobre usmeritve za bolj kakovostno prostorsko in urbanistično načrtovanje.

\section{Nataša Bratina Jurkovič}

Allinea plus, d. o. o., Ljubljana, Slovenija

E-pošta: natasa.b.jurkovic@allinea.si

\section{Opombe}

${ }^{[1]}$ Raziskava je del avtoričine doktorske disertacije z naslovom Doživljanje bivalnega okolja in vedenje prebivalcev $v$ urbanih soseskah.

${ }^{[2]}$ Po podatkih registrskega popisa je 1. januarja $2011 \mathrm{v}$ mestnih območjih živelo 49,8\% prebivalcev Slovenije (Statistični urad Republike Slovenije, 2011).

${ }^{[3]}$ Navedeni so avtoričini preračuni podatkov v deleže na podlagi števila stanovanj po vrstah stavbe in števila prebivalcev iz registrskega popisa (Statistični urad Republike Slovenije, 2011).

${ }^{[4]}$ Standardi za zelene površine $v$ Mestni občini Ljubljana so določeni tako: "Za vsako novo stanovanje $v$ večstanovanjski stavbi je treba zagotoviti najmanj $15 \mathrm{~m}^{2}$ zelenih površin. Od tega mora biti najmanj $5 \mathrm{~m}^{2}$ površin zagotovljenih za igro z žogo za potrebe večjih otrok in mladostnikov ter najmanj $7,5 \mathrm{~m}^{2}$ površin namenjenih in urejenih za igro mlajših otrok (do 12 let) in za počitek stanovalcev, in sicer $4 \mathrm{~m}^{2}$ za igralne površine in $3,5 \mathrm{~m}^{2}$ za zelene površine.» (Odlok o občin- skem prostorskem načrtu Mestne občine Ljubljana - izvedbeni del, Ur. I. RS, št. 78/2010: 11441.)

[5] „Razporeditev območij zelenih površin v strnjenih urbanih območjih je treba načrtovati tako, da je omogočena desetminutna in varna peš dostopnost prebivalcem. (Uredba o Prostorskem redu Slovenije, Ur. I. RS, št. 122/2004: 14711.)

${ }^{[6]}$ Območje obsega prostor med Dunajsko cesto (na vzhodni strani), Mašera-Spasićevo ulico (na severni strani), del Podmilščakove ulice in železniške proge Ljubljana-Kamnik (na zahodni strani) in Kurilniško ulico (na južni strani).

[7] Prebivalci si želijo povezanega sistema zelenih površin, da bi bile omogočene neprometne zelene navezave na poti do mestnega parka Tivoli in priljubljenih mestnih sprehajalno-rekreacijskih območij gozdnatih vzpetin, kot so Rožnik, Mostec in Šmarna gora.

\section{Viri in literatura}

Abu-Ghazzeh, T. (1999): Communicating behavioral research to campus design: Factors affecting the perception and use of outdoor spaces at the University of Jordan. Environment and Behavior, 31(6), str. 764-804. DOI: 10.1177/00139169921972344

Barker, R. G. (1968): Ecological psychology: Concepts and metohods for studying the environment of human behavior. Standford, Standford University Press.

Barbour, R. (2007): Doing focus groups. London, Sage Publications Ltd.

Bechtel, R. B. (1997): Environment and behavior: An introduction. Thousand Oaks, Sage Publications.

Bechtel, R. B., Churchman, A., in Ts'erts'man, A. (2002): Handbook of environmental psychology. New York, John Wiley \& Sons.

Bizjak, I. (2012): Izboljšanje javne participacije pri prostorskem načrtovanju s pomočjo orodij spleta 2.0. Urbani izziv, 23(1), str. 36-48. DOI: 10.5379/urbani-izziv-2012-23-01-004

Bratina, N. (1997): Doživljanje mestnega odprtega prostora - Bevkov trg v Novi Gorici. Urbani izziv, 32-33, str. 60-68. DOI: 10.5379/urbaniizziv-1997-32-33-007

Bratina, N., in Lah Sušnik, M. (1997): Doživljanje mestnega odprtega prostora. Seminarska raziskovalna naloga. Ljubljana, Univerza v Ljubljani, Biotehniška fakulteta, Oddelek za krajinsko arhitekturo.

Carr, S., Francis, M., Rivlin, L. G., in Stone, A. M. (1992): Public space. Cambridge, Cambridge University Press.

Cassidy, T. (1997): Environmental psychology: Behavior and experience in context. East Sussex, Psychology Press.

Cigoj, N., in Gazvoda, D. (2008): Spreminjanje podobe naselij enodružinskih hiš: primerjalna analiza naselij v Ljubljani, Mariboru in Novem mestu. Urbani izziv, 19(1), str. 25-34. DOI: 10.5379/urbaniizziv-2008-19-01-003

Cooper, T. L. (2012): The Responsible administrator: An aproach to ethics for the administrative role. San Francisco, John Wiley \& Sons.

Flick, U. (2009): Doing focus groups. London, Sage Publications.

Frick, D. (ur.). (1986): The quality of urban life: Social psychological and physical conditions. New York, Walter de Gruvter \& Co. DOI: $10.1515 / 9783110884968$

Fuller, R. A., in Gaston, K. J. (2009): The scaling of green spaces coverage in European cities. Biology Letters, 5(3), str. 352-355. DOI: 10.1098/ rsbl.2009.0010 
Gazvoda, D. (2001): Vloga in pomen zelenega prostora v novejših slovenskih stanovanjskih soseskah. Urbani izziv, 12(2), str. 35-42. DOI: 10.5379/urbani-izziv-2001-12-02-004

Gifford, R. (1987): Environmental psychology: Principles and practices. Needham Heights, MA, Allyn \& Bacon.

Goličnik, B. (2005): Okoljsko-vedenjske študije: most sodelovanja med načrtovalci in uporabniki odprtih prostorov. Urbani izziv, 16(2), str. 5561. DOI: 10.5379/urbani-izziv-2005-16-02-006

Goličnik, B. (2006): Vedenjski zemljevidi Ljubljanskih trgov in parkov: Novi izzivi in pogledi na načrtovanje in urejanje prostora. Ljubljana, Urbanistični inštitut Republike Slovenije.

Gulič, P., Polič, M., Rozin Šarec, L., Vovk, M., in Kozmik, V. (1985): Načini vedenja prebivalcev $v$ urbanem prostoru kot osnova za njegovo samoupravno preoblikovanje. Raziskovalna naloga. Ljubljana, Urbanistični inštitut Republike Slovenije.

Ho, D. C. W., Yau, Y., Law, Poon, S. W., Yip, H. K. in Liusman, E. (2012): Socialna zdržnost pri urbani prenovi: ocena želja skupnosti. Urbani izziv, 23(1), str. 49-63. DOI: 10.5379/urbani-izziv-2012-23-01-005

Jacobs, J. (2009): Umiranje in življenje velikih ameriških mest. Ljubljana, Studia humanitatis.

Jankovič Grobelšek, L. (2012): Za javnost odprt zasebni prostor kot dopolnitev omrežja mestnega javnega prostora. Urbani izziv, 23(1), str. 25-35. DOI: 10.5379/urbani-izziv-2012-23-01-003

Jole, M. (2008): Javnost v parkih, med opazovanjem in delovanjem. Primer Pariza. Urbani izziv, 19(2), str. 53-58. DOI: 10.5379/urbani-izziv-2008-19-02-007

Kaplan, R., Kaplan, S., in Ryan, L. R. (1998): With people in mind. Washington, DC, Island Press.

Kearney, A. R. (2006): Residental development patterns and neighborhood satisfaction. Impact of Density and Nearby Nature. Environment and Behavior, 38 (1), str. 112-139. DOI: 10.1177/0013916505277607

Kim, Y., in Kaplan, R. (2004): Physical and psychological factors in sense of community: New urbanist Kentlands and nearby Orchard village. Environment and Behavior, 36(3), str. 313-340. DOI: $10.1177 / 0013916503260236$

Kim, Y. O., in Penn, A. (2004): Linking the spatial syntax of cognitive maps to the spatial syntax of the environment. Environment and Behavior, 36(4), str. 483-504. DOI: 10.1177/0013916503261384

Kyttä, M. (2011): The inhabitant friendly, health promoting urban structure. Prispevek je bil predstavljen na konferenci, z naslovom An international conference on Research into Inclusive Outdoor Environments for All, ki je potekala od 27. do 29. junija v Edinburgu v Veliki Britaniji, str. 11-18.

Kuipers, B, Teccuci, D., in Stankiewicz, B. J. (2003): The skeleton in the cognitive map: A computational empirical exploration. Environment and Behavior, 35(1), str. 81-106. DOI: 10.1177/0013916502238866

Larco, N., Steiner, B., Stockard, J., in West, A. (2012): Pedestrian - friendly environments and active travel for residents of multifamily housing: The role of preferences and perceptions. Environment and Behavior, 44(3), str. 303-333. DOI: 10.1177/0013916511402061

Lynch, K. (1960): The image of the city. Cambridge, MA, MIT Press.

Lynch, K. (2010): Podoba mesta. Novo mesto, Založba Goga.

Lee, T. (1976): Psychology and the environment. London, Methuen.

Lendholt, W. (1970): Funkcija mestnega zelenja. V: Ogrin, D. (ur): Zelenje v urbanem okolju. str. 1-25, Ljubljana, Univerza v Ljubljani, Biotehniška fakulteta, Inštitut za vrtnarstvo in oblikovanje krajine.
Massam, B. H. (2002): Quality of life: Public planning and private living. Danvers, MA, Pergamon.

Mehrabian A., in Russell, J. A. (1974): An approach to environmental psychology. London, Holt.

Megla, M. (2012): Človeško telo in mesta so živi organizmi. Intervju z Lio Ghilardi, urbano sociologinjo. Delo, Sobotna priloga, 51(49), 3. 3. 2012, str. 26-28.

Mestna občina Ljubljana (2010): European green capital application. Ljubljana.

Morgan, D. L. (1998): Focus group kit - Planning focus groups. Thousand Oaks, Sage Publications.

Moughtin, C. (2003): Urban design: Street and square. Boston, Massachusetts Architectural Press.

Noiseux, K., in Hostetler, M. E. (2010): Do homebuyers want green features in their communities? Environment and Behavior, 42(5), str. 551580. DOI: $10.1177 / 0013916508326470$

Odlok o občinskem prostorskem načrtu Mestne občine Ljubljana - izvedbeni del. Uradni list Republike Slovenije, št. 78/2010. Ljubljana.

Pallares-Barbera, M., Badia, A., in Duch, J. (2011): Cerdà in Barcelona: potreba po novem mestu in zagotavljanju storitev. Urbani izziv, 22(2), str. 49-63. DOI: 10.5379/urbani-izziv-2011-22-02-005

Polič, M., Čuk, M., Musek, J., Marjanovič Umek, L., Umek, P., in Tušak, M. (1984): Ekopsihološka raziskava življenja v mestu. Ljubljana, Univerza Edvarda Kardelja v Ljubljani, Filozofska fakulteta, Znanstveni inštitut.

Polič, M., Mencin, M., Marušič, I., in Bartol., B. (1991): Stališča prebivalcev občine Grosuplje do nekaterih vidikov njenega razvoja. Grosuplje, Občina Grosuplje.

Polič, M., Klemenčič, M., Kos, D., Kučan, A., Marušič, I., Natek, K., idr. (2002): Spoznavni zemljevid Slovenije. Ljubljana, Univerza v Ljubljani, Znanstveni inštitut Filozofske fakultete.

Porteous, J. D. (1977): Environment and behavior: Planning and everyday urban life. Reading, MA, Addison-Wesley.

Potter, J., in Cantarrero, R. (2006): How does increasing population and diversity affect resident satisfaction? A small community case study. Environment and Behavior, 38(5), str. 605-625. DOI: $10.1177 / 0013916505284797$

Proshansky, H. M., Ittelson, W. H., in Rivlin, L. G. (1972): Freedom of choice and behavior in a physical setting. V: Wohlwill, J. F., in Carson, D. H. (ur.): Environment and the social sciences: Perspectives and applications, str. 29-43. Washington, DC, American Psychological Association.

Rus, A., Stanič, I., Kos, D., Passler, R., in Vlaj, S. (1994): Členitev mesta Ljubljana: 2. faza. Ljubljana, Urbanistični inštitut Republike Slovenije.

Sendi, R. (2005): Sodelovanje stanovalcev kot pogoj za uspešno izvedbo prenove stanovanjskih sosesk. Urbani izziv, 16(2), str. 5-15. DOI: 10.5379/urbani-izziv-2005-16-02-001

Skifter Andersen, H. (2011): Razlaga preferenc do okolice in lokacije doma. Urbani izziv, 22 (1), str. 22-36. DOI: 10.5379/urbani-izziv-2011-22-01-002

Simoneti, M. (1996): Sodelovanje z meščani, možnost za odgovorno rabo in zadovoljivo urejenost javnih zelenih površin. V: Hudoklin, J. (ur.): Urejanje odprtega prostora v urbanem okolju, str. 49-58. Ljubljana, Društva krajinskih arhitektov Slovenije.

SLONEP (2011): Mesta so prostor, kjer živi več kot polovica vsega prebivalstva. Dostopno na: http://www.slonep.net (sneto 6. 1. 2014). 
Smaniotto Costa, C., Šuklje Erjavec, I., in Mathey, J. (2008): Zelene površine - najpomembnejši vir za sonaravnost mest. Metoda GreenKeys za razvoj zelenih površin. Urbani izziv, 19(2), str. 95-109. DOI: 10.5379/ urbani-izziv-2008-19-02-012

Stewart, D., Shamdasani, P., in Rook, D. (2007): Focus groups: Theory and practice. Thousand Oaks, Sage Publications.

Sugiyama, T., Ward Thompson, C., in Alves, S. (2009): Associations between neighborhood open space attributes and quality of life for older people in Britain. Environment and Behavior, 41(1), str. 3-21. DOI: $10.1177 / 0013916507311688$

Sullivan, W., Kuo, F. E., in DePooter, S. F. (2004): The fruit of urban nature. Environment and Behavior, 36(5), str. 678-700.

DOI: 10.1177/0193841X04264945

Sullivan, W. (2011): Landscape and health and hope. Prispevek je bil predstavljen na konferenci, $z$ naslovom An international conference on Research into Inclusive Outdoor Environments for All, ki je potekala od 27. do 29. junija v Edinburgu v Veliki Britaniji, str. 33-38.

Statistični urad Republike Slovenije (2011): Registrski popis 2011. Ljubljana.

Šarič, M. (2007): Fokus skupine v psihološkem raziskovanju. Psihološka obzorja, 16(3), str. 125-138.

Trajekt - Zavod za prostorsko kulturo (2012): Trajnostno mesto Berlin. Dostopno na: http://trajekt.org (sneto 10. 1. 2014)

Uredba o Prostorskem redu Slovenije. Uradni list Republike Slovenije, št.122/2004. Ljubljana.

Vertelj Nared, P., in Simoneti, M. (2011): Analiza podatkovnih baz o mestnih zelenih površinah kot izhodišče za razpravo o povezavi med kakovostjo in uporabnostjo podatkov. Geodetski vestnik, 55(2), str. 366-379.

Wandersman, A. (1976): Applying humanism, behaviorism and a broader social developmental view to understanding and researching the design process. The Behavioral Basis of Design, str. 9-20.

Wandersman, A. (1979): User participation in planning environments: A conceptual framework. Environment and Behavior, 11(4), str. 465-482. DOI: $10.1177 / 0013916579114003$

Ward Thompson, C. (2010): Landscape quality and quality of life. V: Ward Thompson, C., Aspinall, P., in Bell, S. (ur.): Innovative aproaches to researching landscape and health - Open space: People space 2, str. 230 255. Routledge, Taylor \& Francis Group.

Wiena International (2014): Dunaj, okoljsko osveščeno mesto - 50:50 zelenih površin. Dostopno na: http://www.wieninternational.at (sneto 6. 1. 2014).

Wu, W. (2013): Does public investment improve homeowners' happiness? New evidence based on micro surveys in Beijing. Urban Studies, 1(18). DOI: 10.1177/0042098013484530

Zeisel, J. (2006): Inquiry by design: environment / behavior / neuroscience in architecture, interiors, landscape and planning. New York, Northon. 